\title{
Absorption and fluorescence properties of chromophoric dissolved organic matter of the eastern Bering Sea in the summer with special reference to the influence of a cold pool
}

\author{
E. J. D'Sa ${ }^{1}$, J. I. Goes ${ }^{2}$, H. Gomes ${ }^{2}$, and C. Mouw ${ }^{3}$ \\ ${ }^{1}$ Department of Oceanography and Coastal Sciences, Louisiana State University, Baton Rouge, LA, USA \\ ${ }^{2}$ Lamont-Doherty Earth Observatory, NY, USA \\ ${ }^{3}$ Michigan Technological University, MI, USA
}

Correspondence to: E. J. D’Sa (ejdsa@1su.edu)

Received: 18 November 2013 - Published in Biogeosciences Discuss.: 6 December 2013

Revised: 6 May 2014 - Accepted: 7 May 2014 - Published: 17 June 2014

\begin{abstract}
The absorption and fluorescence properties of chromophoric dissolved organic matter (CDOM) are reported for the inner shelf, slope waters and outer shelf regions of the eastern Bering Sea during the summer of 2008, when a warm, thermally stratified surface mixed layer lay over a cold pool $\left(<2{ }^{\circ} \mathrm{C}\right)$ that occupied the entire middle shelf. CDOM absorption at $355 \mathrm{~nm}\left(a_{\mathrm{g}} 355\right)$ and its spectral slope $(S)$ in conjunction with excitationemission matrix (EEM) fluorescence and parallel factor analysis (PARAFAC) revealed large variability in the characteristics of CDOM in different regions of the Bering Sea. PARAFAC analysis aided in the identification of three humic-like (components one, two and five) and two proteinlike (a tyrosine-like component three, and a tryptophanlike component four) components. In the extensive shelf region, average absorption coefficients at $355 \mathrm{~nm}\left(a_{\mathrm{g}} 355, \mathrm{~m}^{-1}\right)$ and DOC concentrations $(\mu \mathrm{M})$ were highest in the inner shelf $\left(0.342 \pm 0.11 \mathrm{~m}^{-1}, 92.67 \pm 14.60 \mu \mathrm{M}\right)$ and lower in the middle $\left(0.226 \pm 0.05 \mathrm{~m}^{-1}, 78.38 \pm 10.64 \mu \mathrm{M}\right)$ and outer $\left(0.185 \pm 0.05 \mathrm{~m}^{-1}, 79.24 \pm 18.01 \mu \mathrm{M}\right)$ shelves, respectively. DOC concentrations, however were not significantly different, suggesting CDOM sources and sinks to be uncoupled from DOC. Mean spectral slopes $S$ were elevated in the middle shelf $\left(24.38 \pm 2.25 \mu^{-1}\right)$ especially in the surface waters $\left(26.87 \pm 2.39 \mu^{-1}\right)$ indicating high rates of photodegradation in the highly stratified surface mixed layer, which intensified northwards in the northern middle shelf likely contributing to greater light penetration and to phytoplankton blooms at deeper depths. The fluorescent humic-like com-
\end{abstract}

ponents one, two, and five were most elevated in the inner shelf most likely from riverine inputs. Along the productive "green belt" in the outer shelf/slope region, absorption and fluorescence properties indicated the presence of fresh and degraded autochthonous DOM. Near the Unimak Pass region of the Aleutian Islands, low DOC and $a_{\mathrm{g}} 355$ (mean $66.99 \pm 7.94 \mu \mathrm{M} ; 0.182 \pm 0.05 \mathrm{~m}^{-1}$ ) and a high $S$ (mean $25.95 \pm 1.58 \mu \mathrm{m}^{-1}$ ) suggested substantial photobleaching of the Alaska Coastal Water, but high intensities of humic-like and protein-like fluorescence suggested sources of fluorescent DOM from coastal runoff and glacier meltwaters during the summer. The spectral slope $S$ vs. $a_{\mathrm{g}} 355$ relationship revealed terrestrial and oceanic end members along with intermediate water masses that were modeled using nonlinear regression equations that could allow water mass differentiation based on CDOM optical properties. Spectral slope $S$ was negatively correlated $\left(r^{2}=0.79\right)$ with apparent oxygen utilization (AOU) for waters extending from the middle shelf into the deep Bering Sea indicating increasing microbial alteration of CDOM with depth. Although our data show that the CDOM photochemical environment of the Bering Sea is complex, our current information on its optical properties will aid in better understanding of the biogeochemical role of CDOM in carbon budgets in relation to the annual sea ice and phytoplankton dynamics, and to improved algorithms of ocean color remote sensing for this region. 


\section{Introduction}

The eastern Bering Sea is one of the most productive marine ecosystems in the world sustaining nearly half of the US fish landings annually (Walsh and McRoy, 1986; Sigler et al., 2010). However, there is now increasing evidence that the ecosystem of the Bering Sea is sensitive to climate change (Grebmeier et al., 2006; Overland and Stabeno, 2004). Since waters entering the Arctic through the Bering Strait are modified as they cross the Bering Sea shelf, any changes in the dissolved organic matter (DOM) pool in the Bering Sea could also impact the sensitive Arctic region, which plays an important role in global carbon cycling (Shaver et al., 1992; Benner et al., 2004). Although Pacific origin waters flowing through the Bering Sea and the Bering Strait have been shown to influence dissolved organic carbon (DOC) concentrations and the optical properties of the colored or chromophoric dissolved organic matter (CDOM) in the western Arctic (Cooper et al., 2005; Gueguen et al., 2012), very limited information is available on the characteristics and properties of CDOM of the Bering Sea (Sasaki et al., 2001).

CDOM is an important component of DOM. Through its absorption of UV and visible light, CDOM influences light penetration and primary productivity in aquatic ecosystems, plays a key role in photochemically induced transformations in surface waters, and also protects organisms from UV damage (Mopper and Kieber, 2002; Coble, 2007). Its absorption in the visible band has been shown to interfere with satellite ocean color estimates of phytoplankton chlorophyll (Chl) in aquatic systems including the eastern Bering Sea and western Arctic Ocean (Siegel et al., 2002; Gregg and Casey, 2004; D'Sa, 2008; Matsuoka et al., 2007; Naik et al., 2013). CDOM can be produced in situ by biological production (authochthonous, primarily microbial remineralization of organic matter) or transported from terrestrial sources (allochthonous) and removed by photochemical degradation and microbial consumption or influenced by physical processes such as circulation, upwelling or mixing (Hansell and Carlson, 2002; D'Sa et al., 2006; Coble, 2007; Nelson and Siegel, 2013). Its presence in the form of humic, fulvic, and amino acids imparts characteristic absorption and fluorescence properties that can be used to characterize its composition and diagenetic state (Mopper and Schultz, 1993; Coble, 1996; Stedmon and Markager, 2005a; Blough and Del Vecchio, 2002; Nelson et al., 2010).

Absorption spectral indices such as spectral slopes have been used to gain insights into source, composition and reactivity of CDOM (Moran et al., 2000; Blough and Del Vecchio, 2002 and references therein). The photodegradation of CDOM for example results in the loss of CDOM absorption and increases the spectral slope (Del Vecchio and Blough, 2004; D'Sa and DiMarco, 2009). The use of spectral slopes over narrow wavelength intervals, e.g., $275-295 \mathrm{~nm}$ ( $S$ or $S_{275-295}$ ) have been shown to provide information on $\mathrm{C}(\mathrm{DOM})$ source, photooxidative degradation, molecular size distribution, and microbial activity with steeper slopes for example signifying lower molecular weight material and vice-versa (Blough and Del Vecchio, 2002; Helms et al., 2008). Shorter wavelength spectral slope parameters have been found to be the best indicators of photodegradation with increases in the spectral slope $S$ strongly correlating to apparent removal of CDOM absorption (Granskog, 2012; Fichot and Benner, 2012; Yamashita et al., 2013).

Fluorescence properties of CDOM in natural waters have been studied using excitation-emission matrix (EEM) fluorescence spectroscopy (Coble, 1996, 2007) wherein a threedimensional fluorescence intensity landscape is obtained across a range of excitation (e.g., $250-450 \mathrm{~nm}$ ) and emission (e.g., 290-550 nm) wavelengths. The fluorescent constituents of DOM are known to include humic substances and bound or free amino acids, and the use of excitation-emission matrices (EEMs) provides information on changes in CDOM resulting from mixing, biological degradation, biological production, and photobleaching, including its chemical composition and origin (Mopper and Schultz, 1993; Coble, 1996, 2007). The presence of protein-like substances generally implies autochthonous production of CDOM or microbial activity while humic-like material can indicate allochthonous sources (Mopper and Schultz, 1993; Coble, 1996; Mayer et al., 1999; Stedmon and Markager, 2005a, b; Yamashita et al., 2008). Recent experiments however have shown that phytoplankton can directly contribute to the autochthonous production of marine humic-like substances (Romera-Castillo et al., 2010). The combination of EEMs with parallel factor analysis (PARAFAC) allows for the chemical identification of fluorophores (Stedmon et al., 2003; Stedmon and Markager, 2005a; Stedmon and Bro, 2008; Kowalczuk et al., 2009; Singh et al., 2010). PARAFAC decomposes an EEM data set into least-squares sum of several mathematically independent components to efficiently resolve and identify the different classes of fluorophores in an environment. Recent studies of EEMs and PARAFAC analysis in the Arctic have identified various humic-like and protein-like fluorophores that have been linked to the Bering Sea waters (Gueguen et al., 2005, 2012).

The Bering Sea with its wide shallow shelf $(\sim 500 \mathrm{~km}$ wide), shelf break, deep basins and a dynamic ocean circulation system has a highly complex ecosystem (Wang et al., 2013). During winter, winds mix the water column of the eastern Bering Sea to $\sim 100 \mathrm{~m}$. During spring-summer, distinct hydrographic characteristics develop in the inner (0-50 m depth), middle (50-100 m), and outer (100-200 m) shelves/domains that are separated by physical structural fronts or transitional zones (Schumacher and Stabeno, 1998). The inner shelf or the Coastal Domain is well mixed due to an overlapping upper wind-mixed layer and a lower tidally mixed layer. A two-layered structure develops in the middle shelf with an upper wind mixed and a lower tidally mixed layer, while in the outer shelf the two layers are separated by a region of gradually increasing density. The shelf has 
been further divided into northern and southern regions with a demarcation at $\sim 60^{\circ} \mathrm{N}$ (Stabeno et al., 2012a). Circulation on the shelf is complicated with the Alaskan Stream flowing along the Aleutian Peninsula and supplying some of its water via Aleutian passes to the Bering Slope Current (BSC), the Aleutian North Slope Current (ANSC), and the Alaskan Coastal Water (ACW) or Alaskan Coastal Current (ACC) (Fig. 1) (Coachman, 1986; Stabeno et al., 1999). On the broad eastern shelf, currents are northwestward following the topographic isobaths and the ACW, while along the "green belt", a highly productive habitat along the edge of the continental shelf, mesoscale eddy motion promotes exchange of water between the shelf and the deep basin that contributes to enhanced primary productivity (Stabeno and Van Meurs, 1999; Wang et al., 2013). The seasonal advance, retreat and extent of sea ice in the Bering Sea strongly influences the physical properties and the biological communities of the region (Sigler et al., 2010; Stabeno et al., 2012a; Goes et al., 2014). In fact, the areal extent and rate of retreat of sea ice can determine the conditions that will develop over the Bering Sea shelf in the following summer, such as the formation of the cold pool associated with the winter water over the middle shelf (Zhang et al., 2012; Stabeno et al., 2012b). The cold pool or a region with bottom waters with temperatures $<2{ }^{\circ} \mathrm{C}$ is tied to stratification which begins in April/May. Waters overlying the cold pool become progressively warmer further insulating the bottom layer and preventing it from warming as the season progresses. Water temperatures in the cold pool depend on winter sea ice conditions as well as the temperature of the water column at the onset of stratification. In cold years, with extensive sea ice present through April, cold bottom temperatures usually remain below $2{ }^{\circ} \mathrm{C}$ throughout the summer and the strong density gradient that develops prevents the spring bloom from settling to the benthic layer as in years when the cold pool is absent (Goes et al., 2014). Sea ice extent is predicted to decrease under future climate scenario (Stabeno et al., 2012b) with potential impacts on the biogeochemical processes of the eastern Bering Sea.

In this study, we present results of an extensive set of DOC, CDOM absorption and fluorescence measurements obtained in various regions of the eastern Bering Sea in the summer of 2008 when a cold pool was present over the entire middle shelf. CDOM absorption coefficients $a_{\mathrm{g}} 355$, and spectral slope $S_{275-295}$ (or $S$ ), along with PARAFAC analysis of EEM data are used to examine compositional distribution and CDOM variation and linkages to hydrography, Chl, apparent oxygen utilization (AOU) and DOC concentrations in the eastern Bering Sea.

\section{Data and methods}

\subsection{Field sampling}

The data was collected as part of a NASA funded study on the impacts of sea-ice changes on the bio-optical properties of the Bering Sea through participation on a Bering Ecosystem Study-Bering Sea Integrated Ecosystem Research Program (BEST-BSIERP) field campaign on board the US Coast Guard Cutter Healy from 1-31 July 2008. CTD stations in general, were aligned along cross-shelf transects that spanned the inner, middle, and outer shelf/slope regions. The cruise track also included an alongshore, northsouth transect along the $70 \mathrm{~m}$ isobath within the middle shelf (Fig. 1). Hydrographic data were collected with a SeaBird SBE-911 plus CTD unit that recorded depth, temperature, salinity along with dissolved oxygen and Chl fluorescence at every station. The Sea-Bird SBE 43 dissolved oxygen was calibrated using Winkler method while chlorophyll concentrations were obtained from a factory calibrated Chelsea Aqua 3 fluorometer using the Sea-Bird software; no additional calibration with discrete chlorophyll measurements were conducted in this study. The Apparent Oxygen Utilization (AOU) was calculated using the Ocean Data Viewer (Schlitzer, 2004). Water samples were collected during CTD casts from Niskin bottles attached to a carousel rosette sampler generally at three depths (surface, mid-1, and mid-2) for DOC, fluorescence, and absorption (plus additional depths for absorption) measurements. The mid-1 depth corresponded to the $\mathrm{Chl}$ fluorescence maximum if present at that station, and the mid-2 depth was below the Chl maxima and where Chl fluorescence was low.

\subsection{CDOM Absorption measurements}

Water samples obtained from Niskin bottles were filtered immediately through $0.2 \mu$ m nylon membrane filters under low vacuum. Most samples were immediately analyzed on board or stored at $4{ }^{\circ} \mathrm{C}$ in the dark, in acid cleaned, pre-combusted amber bottles for laboratory analysis. After the filtered samples were allowed to reach ambient room temperature, absorbance measurements of $\operatorname{CDOM}(A(\lambda))$ were obtained on a World Precision Instruments (WPI) Ultrapath ${ }^{\mathrm{TM}}$ system from $190-722 \mathrm{~nm}$ using a path length of either 10 or $50 \mathrm{~cm}$ and based on the absorbance observed between $400-500 \mathrm{~nm}$. To minimize differences in refractive index between sample and reference which cause offsets in absorbance measurements (D'Sa et al., 1999; D'Sa and DiMarco, 2009), a reference salt solution was prepared using granular $\mathrm{NaCl}$ (Mallinckrodt) and Milli-Q water to closely match the seawater samples. Absorbance data were corrected over a $10 \mathrm{~nm}$ interval of the measured absorbance at $700 \mathrm{~nm}$ from each wavelength and the $a_{\mathrm{g}}(\lambda)\left(\mathrm{m}^{-1}\right)$ was calculated using the equation:

$a_{\mathrm{g}}(\lambda)=2.303 \times \frac{A(\lambda)}{l}$. 


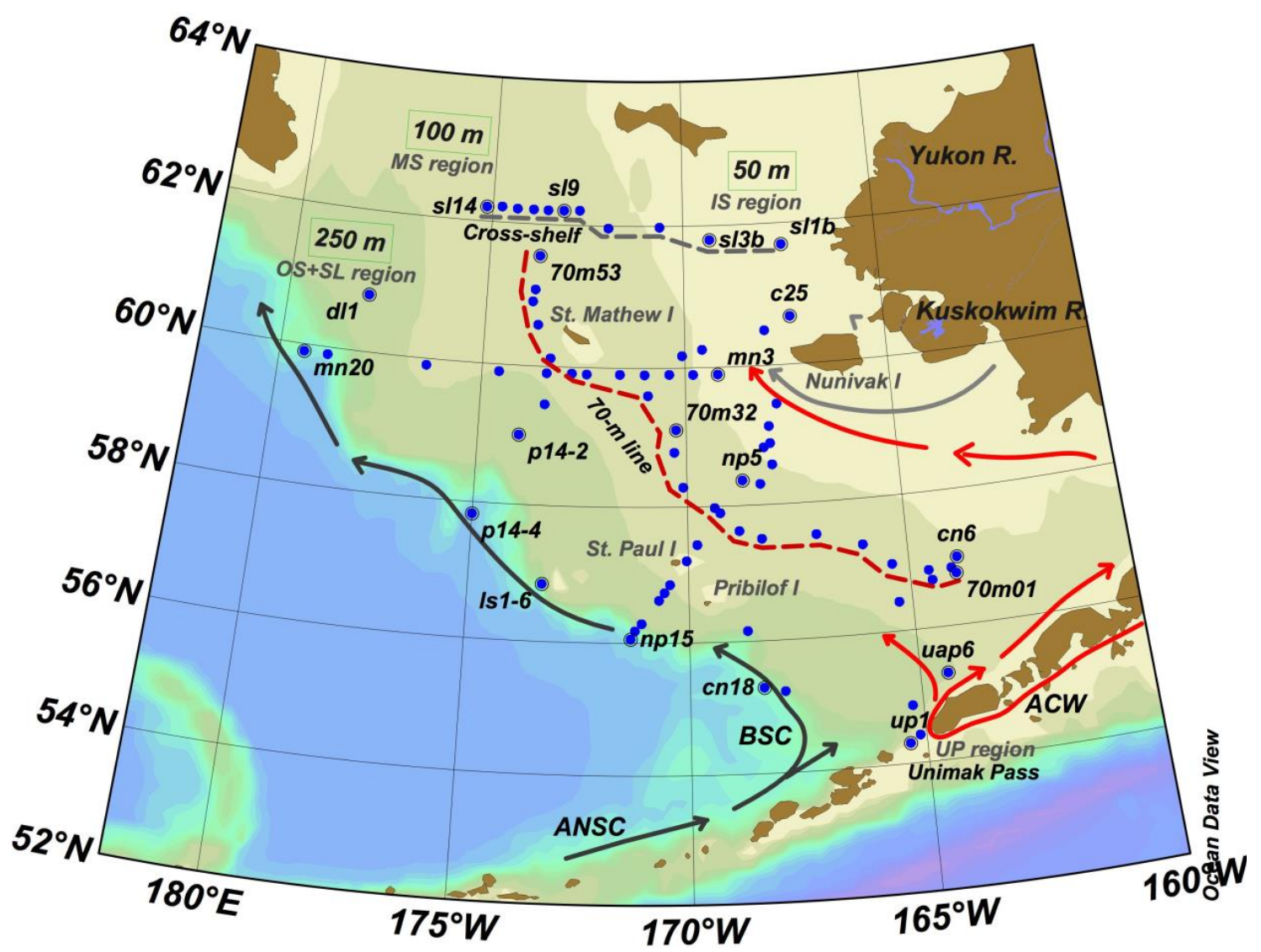

Figure 1. Map of study area showing the station locations (blue circles) sampled during a cruise in July 2008. Depth contours (50, 100 and $250 \mathrm{~m}$ ) demarcate the boundaries of the inner, middle and outer shelves. Cross-shelf (SL) transect and north-south $70 \mathrm{~m}$ line are shown and discussed in text. General circulation patterns showing Alaska Coastal Water (ACW), the Aleutian North Slope Current (ANSC), and the Bering Slope Current (BSC). The optical properties of the various regions sampled are also described in Tables 1 and 3.

Absorption coefficient at $355 \mathrm{~nm}\left(a_{\mathrm{g}} 355\right)$ was used as a quantitative parameter of CDOM. The spectral slopes for the intervals of $275-295 \mathrm{~nm}\left(S\right.$ or $\left.S_{275-295}\right)$ were calculated according to Helms et al. (2008) $\left(\mu \mathrm{m}^{-1}\right)$.

\subsection{EEM measurements and PARAFAC model analysis}

EEMs were recorded using a FluoroMax-4 (Jobin Yvon Horiba) fluorometer by scanning the emission spectra from $290-550 \mathrm{~nm}$ at $5 \mathrm{~nm}$ intervals over excitation wavelengths between $250-450 \mathrm{~nm}$ at $5 \mathrm{~nm}$ increments. The fluorescence spectra were corrected for instrument bias using correction files provided by the instrument manufacturer. Normalization of fluorescence intensity was carried out according to the method described in Singh et al. (2010). Re-absorption and inner filter effects were minimal as the absorbance values were $<0.02$ at $250 \mathrm{~nm}$ for the samples analyzed. Milli-Q water blank EEMs were subtracted from the sample EEMs to eliminate Raman peaks and then normalized to dailydetermined water Raman integrated area maximum fluorescence intensity $(350 \mathrm{ex} / 395 \mathrm{em}, 5 \mathrm{~nm}$ bandpass and reported in equivalent water Raman units (R.U.).
The EEMs were modeled by PARAFAC using the DOMFluor toolbox (Stedmon and Bro, 2008). The model was constrained by non-negativity and run for three to seven components. Determination of the number of components (i.e., model validation) was done by split-half analysis using 174 EEMs, including analysis of residuals and loadings (Stedmon et al., 2003). Five components were identified for the data set with some variability remaining in the residuals. These five components captured the bulk features in the measured EEM as indicated by the low residual (difference between measured and modeled data; not shown) and the small differences between the split-half and whole excitation and emission loadings (Fig. 7-bottom right). Leverage and loading technique (Stedmon and Bro, 2008) were used to identify the outliers. PARAFAC analysis decomposed the EEMs into individual components and the fluorescence of each component was represented by the maximum fluorescence in R.U.

\subsection{DOC measurements}

Samples for DOC were collected from Niskin bottles and filtered through precombusted GF/F filters, acidified ( $100 \mu \mathrm{L}$ of 
$2 \mathrm{~N} \mathrm{HCl}$ was added to remove inorganic carbon) and stored at $4{ }^{\circ} \mathrm{C}$ in acid cleaned, pre-combusted amber bottles with Teflon lined caps for laboratory analysis. DOC measurements were made on a Shimadzu TOC 5000A (with ASI$5000 \mathrm{~A}$ autosampler) that uses a high temperature combustion method to convert carbon compounds to carbon dioxide $\left(\mathrm{CO}_{2}\right)$ (Benner and Strom, 1993; Sharp, 2002).

\section{Results}

\subsection{CDOM absorption properties}

\subsubsection{Hydrography and CDOM absorption}

The absorption properties of CDOM are examined in conjunction with hydrography, Chl, AOU, and DOC concentrations (Fig. 2, Table 1). Water masses in the Bering Sea upper layer are influenced by advection of water from the Pacific Ocean, the hydrological cycle between the surface layer and atmosphere, continental drainage and ice formation and melting, while at intermediate and deep depths, the dominant effects are water exchange with the Pacific Ocean and mixing of water by currents (Luchin et al., 1999). Water masses in the eastern Bering Sea during the summer could be divided into three main groups with salinity $<31.3$ for ice melt and river water, 31.3-33 for the Bering shelf water, and 3335 for the deep Bering Sea (DBS) (Fig. 2a and b; Mathis et al., 2010). A pronounced frontal zone divides the shelf waters from the deep basin (Fig. 3a and b); near the Unimak Pass region as in other passes of the Aleutian Islands, vertical mixing and continental runoff in the Gulf of Alaska and from the Aleutian Islands reduces the salinity and temperature (Fig. 3a and b; Luchin et al., 1999). A front that separates the well-mixed inner shelf from the two-layered middle shelf that is generally located near the $50 \mathrm{~m}$ isobath can however vary its position depending on wind, tidal strength, sea ice advance/retreat and storm strength and timing (Schumacher and Stabeno, 1998; Kachel et al., 2002). Thus an overlap in the hydrographic and CDOM optical properties are likely when considering the water masses associated with the different shelf regions based on bathymetry.

CDOM absorption at $355 \mathrm{~nm} \quad\left(a_{\mathrm{g}} 355\right)$ (mean $\left.0.226 \pm 0.072 \mathrm{~m}^{-1}, \quad n=380\right)$ and DOC concentrations (mean $79.72 \pm 0.14 .35 \mu \mathrm{M}, n=202$ ) in the eastern Bering Sea varied in the range $0.098-0.603 \mathrm{~m}^{-1}$ and 51.8 $148.90 \mu \mathrm{M}$, respectively, with the largest variability observed over the inner shelf where terrestrial influences were high (Fig. 2a). The relationship of the absorption coefficient $a_{\mathrm{g}} 355$ to salinity presented three mixing lines associated with different water masses in the eastern Bering Sea (Fig. 2a). For the inner shelf waters, a sharp decrease in absorption $a_{\mathrm{g}} 355$ (mean $0.342 \pm 0.03 \mathrm{~m}^{-1}$ ) over a relatively narrow range in salinity was observed (slope $=-0.19$, $\left.r^{2}=0.34, p<0.001\right)$. A second mixing line trending at lower salinity ( $\sim 31$ to 29.7$)$ was associated with sea ice melt. A third mixing line extending from the middle shelf (mean $0.226 \pm 0.05 \mathrm{~m}^{-1}$ ), the outer shelf/slope (mean $0.185 \pm 0.05 \mathrm{~m}^{-1}$ ) and the DBS (mean $0.150 \pm 0.03 \mathrm{~m}^{-1}$ ) revealed a decreasing trend of absorption with increasing salinity (slope $=-0.03, r^{2}=0.18, p<0.001$ ). However, $a_{\mathrm{g}} 355$ in the deeper DBS waters (depth 1000-2500 m) $\left(0.146 \pm 0.015 \mathrm{~m}^{-1}\right)$ (Fig. 1, stations mn20, p14-4, np15, and cn18; Fig. 2a, data within ellipse) was not significantly different from the DBS waters above (depths $50-1000 \mathrm{~m}$ ) $\left(0.145 \pm 0.020 \mathrm{~m}^{-1}\right)$ indicating a different trend with no loss of CDOM with depth.

The spectral slope $S$ (mean $24.066 \pm 2.97 \mu \mathrm{m}^{-1}$, $n=380$ ) varied over a large range $\left(13.39-34.26 \mu \mathrm{m}^{-1}\right)$ with the largest mean slope in the Unimak Pass (UP) region $\left(25.95 \pm 1.58 \mu^{-1}\right)$ and lowest in the DBS $\left(18.09 \pm 3.75 \mu^{-1}\right)$ (Table 1). Although mean $S$ generally decreased from the inner to outer shelf/slope region with increasing salinity (Table 1, Fig. 2b) there was a large variability in $S$ in the lower salinity waters. However, for samples from the middle shelf to the DBS, $S$ was inversely correlated with salinity (slope $=-2.78, r^{2}=0.49$, $p<0.001)$. The spectral slope $S-a_{\mathrm{g}} 355$ relationship revealed negative correlations for the different water masses that were modeled using a nonlinear regression equation of the form $S=y_{0}+b / a_{\mathrm{g}} 355$ (Stedmon and Markager, 2001). Although the spectral range for the determination of $S$ and the value of the absorption coefficient used in this study differed from that of Stedmon and Markager (2001), trends for terrestrial and oceanic end members were similar (Fig. 2c) with significant correlations $(p<0.0001)$ between $S$ and $a_{\mathrm{g}} 355$ for the inner shelf $\left(r^{2}=0.61, y_{0}=19.80, b=1.36\right.$; line 1$)$, the middle shelf $\left(r^{2}=0.60, y_{0}=16.12, b=1.81\right.$; line 2$)$, the UP region $\left(r^{2}=0.78, y_{0}=20.22, b=0.98\right.$; line 3$)$ and the ice meltwaters $\left(r^{2}=0.62, y_{0}=19.31, b=1.49\right.$; line 4$)$. There was a large scatter in the $S-a_{\mathrm{g}} 355$ relationship for the outer shelf and slope waters with most values however being concentrated in a small range of absorption and slope values $\left(0.12-0.2 \mathrm{~m}^{-1} ; 20-24 \mu \mathrm{m}^{-1}\right)$. A surface value with elevated $S$ was used to model the oceanic end member which consisted mainly of subsurface and deep water samples and is depicted by line 5 ( $y_{0}=0.34, a=2.65$; not significant).

A minimum of AOU $\left(\sim 95 \mu \mathrm{mol} \mathrm{kg}{ }^{-1}\right)$ was associated with subsurface Chl maxima $\left(S \sim 23 \mu \mathrm{m}^{-1}\right)$ in the northern middle shelf (ellipse 2; Figs. $2 \mathrm{~d}$ and $4 \mathrm{c}$ ) that also corresponded to some of the highest $S$ values (ellipse 1) of surface samples with low Chl (Fig. 3c and f). Lowest $S$ values were also associated with waters of river origin or terrestrial source such as the two samples obtained close to the Nunivak and Pribilof Islands. A strong negative correlation was observed between AOU and $S$ (slope $=-0.032, r^{2}=0.79$, $p<0.001$ for AOU $>0$ ) for waters extending from the middle shelf into the deep slope Bering Sea waters (Fig. 2d). The correlation improved $\left(r^{2}=0.85, p<0.0001\right)$ when considering only the outer shelf, slope, and the DBS waters. 

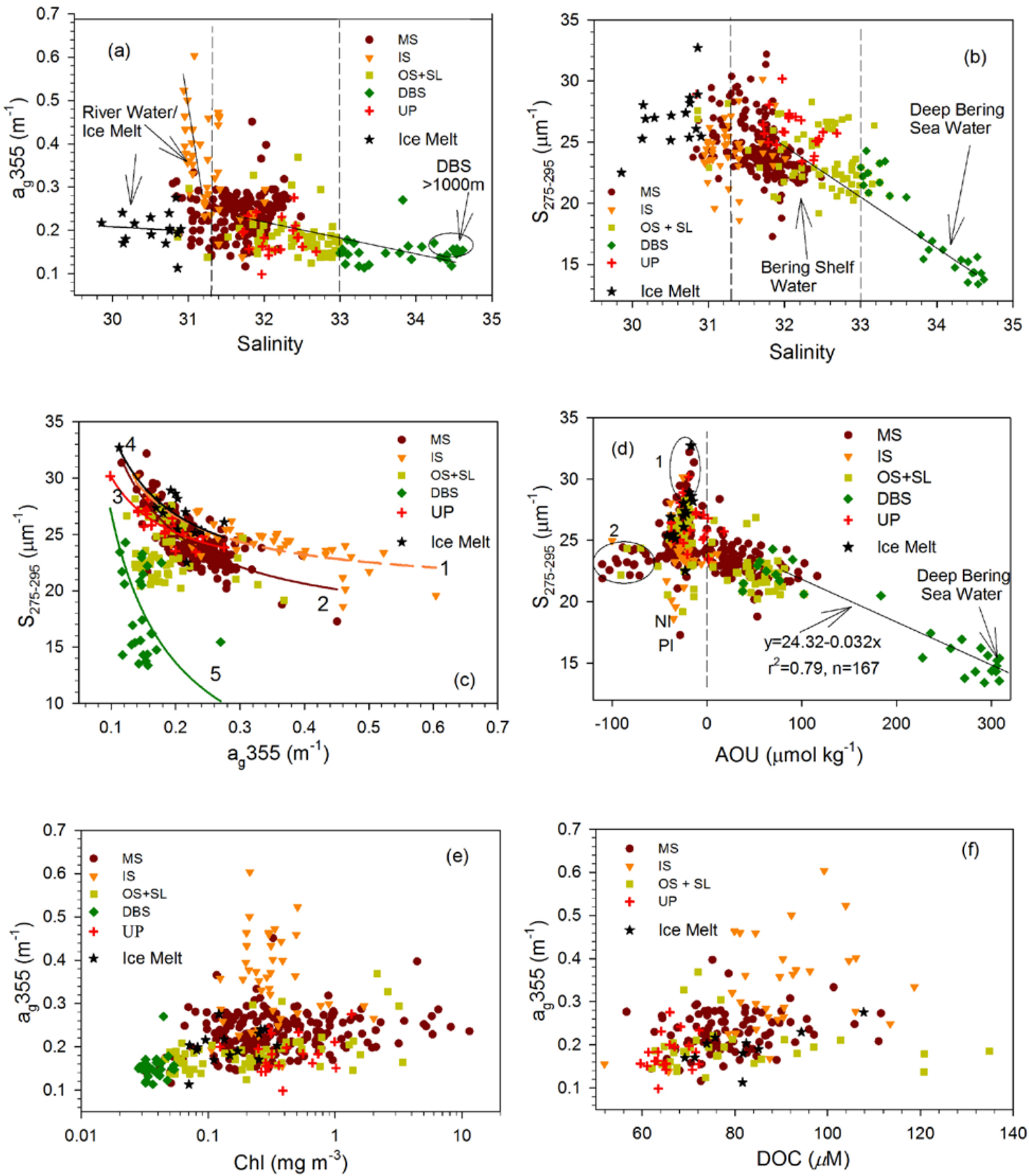

Figure 2. Relationships between (a) salinity and CDOM absorption coefficients at $355 \mathrm{~nm}\left(a_{\mathrm{g}} 355\right)$ (ellipse includes slope samples in the deep Bering Sea at at depths $>1000 \mathrm{~m}$ ), (b) salinity and spectral slope $\left(S\right.$ or $\left.S_{275-295}\right)$, (c) $a_{\mathrm{g}} 355$ and $S$, (d) Apparent Oxygen Utilization (AOU) and $S_{275-295}$, (ellipse 1 includes surface samples and ellipse 2 subsurface at Chl maxima in the northern middle shelf; NI and PI represent Nunivak and Pribilof Islands, respectively) (e) chlorophyll (Chl) and $a_{\mathrm{g}} 355$, and (f) DOC and $a_{\mathrm{g}} 355$. The abbreviations MS, IS, OS, SL, and UP represent the middle shelf, inner shelf, outer shelf, slope and Unimak Pass regions, respectively. DBS represents the deep Bering Sea water with salinity in the range 33-35; the Bering Shelf water salinity ranged from 31.3-33 (dashed lines).

A strong negative correlation was also observed between $S$ and nitrate $\left(r^{2}=0.65, p<0.001\right)$ and a weak but significant negative correlation between $a_{\mathrm{g}} 355$ and nitrate $\left(r^{2}=0.21\right.$, $p<0.001)$.

Excluding the inner shelf waters, a weak but significant positive correlation was observed between $\mathrm{Chl}$ and $a_{\mathrm{g}} 355$
(Fig. 2e; $r^{2}=0.22, p<0.001$ ). Although there was a positive trend, DOC concentrations were not significantly correlated to $a_{\mathrm{g}} 355$ (Fig. 2f) and to Chl (Fig. not shown) for the different shelf regions. 
Table 1. Mean salinity, temperature, Chl fluorescence, DOC concentrations, CDOM absorption at $355 \mathrm{~nm}\left(a_{\mathrm{g}} 355\right)$, and spectral slope $S$ or $S_{275-295}$ measured in different regions (IS-inner shelf, MS-middle shelf, OS-outer shelf, SL-slope, and UP-Unimak Pass) of the Bering Sea. In the MS region, mean values of the properties at the surface, mid-1 and mid- 2 depths are also given. Mean values of the properties in the deep Bering Sea (DBS) with salinity in the range 33-35 are shown.

\begin{tabular}{lcccccc}
\hline region & Salinity & $\begin{array}{c}\text { Temp. } \\
\left({ }^{\circ} \mathrm{C}\right)\end{array}$ & $\begin{array}{c}\text { Chl } \\
\left(\mathrm{mg} \mathrm{m}^{-3}\right)\end{array}$ & $\begin{array}{c}\text { DOC } \\
(\mu \mathrm{M})\end{array}$ & $\begin{array}{c}a_{\mathrm{g}} 355 \\
\left(\mathrm{~m}^{-1}\right)\end{array}$ & $\begin{array}{c}S_{275-295} \\
\left(\mu \mathrm{m}^{-1}\right)\end{array}$ \\
\hline UP & $32.12 \pm 0.28$ & $5.39 \pm 5.35$ & $0.45 \pm 0.2$ & $66.99 \pm 7.94$ & $0.182 \pm 0.05$ & $25.95 \pm 1.58$ \\
IS & $31.18 \pm 0.27$ & $3.51 \pm 2.26$ & $0.37 \pm 0.4$ & $92.67 \pm 14.60$ & $0.342 \pm 0.11$ & $24.63 \pm 2.49$ \\
MS & $31.67 \pm 0.44$ & $2.17 \pm 3.25$ & $0.62 \pm 1.3$ & $78.38 \pm 10.64$ & $0.226 \pm 0.05$ & $24.38 \pm 2.25$ \\
MS-sur & $31.23 \pm 0.54$ & $6.28 \pm 0.98$ & $0.26 \pm 0.32$ & $80.27 \pm 13.78$ & $0.201 \pm 0.04$ & $26.87 \pm 2.39$ \\
MS-mid1 & $31.81 \pm 0.24$ & $0.81 \pm 2.62$ & $1.78 \pm 2.47$ & $77.32 \pm 10.04$ & $0.242 \pm 0.05$ & $23.72 \pm 1.58$ \\
MS-mid2 & $31.92 \pm 0.22$ & $-0.37 \pm 1.2$ & $0.49 \pm 0.77$ & $78.93 \pm 11.42$ & $0.231 \pm 0.03$ & $23.27 \pm 1.52$ \\
OS + SL & $32.36 \pm 0.52$ & $3.99 \pm 2.75$ & $0.47 \pm 0.73$ & $79.24 \pm 18.00$ & $0.185 \pm 0.05$ & $23.48 \pm 2.31$ \\
DBS & $33.79 \pm 0.59$ & $2.81 \pm 0.78$ & $0.04 \pm 0.0$ & - & $0.150 \pm 0.03$ & $18.09 \pm 3.75$ \\
\hline
\end{tabular}

\subsubsection{Horizontal spatial variability}

The spatial distribution of the absorption properties of CDOM were examined in conjunction with temperature, salinity, Chl and DOC concentrations for surface (Fig. 3a-f), and mid-1 depth (Fig. 4a-f) located at the Chl maxima of the eastern Bering Sea. Surface temperature was relatively high $\left(6-8^{\circ} \mathrm{C}\right)$ except at the inner shelf and around the Nunivak Islands where cooler waters extended westward and southward into the middle shelf (Fig. 3a). In contrast, subsurface waters were coldest in the northern $\left(<-1^{\circ} \mathrm{C}\right)$ and southern middle shelf $\left(<2^{\circ} \mathrm{C}\right)$ (Fig. $\left.4 \mathrm{a}\right)$ revealing the presence of a "cold pool". Salinity in both surface and subsurface waters increased from inner shelf $(31.18 \pm 0.27)$, the middle shelf $(31.67 \pm 0.44)$ to outer shelf/slope $(32.36 \pm 0.52)$ and the UP region ( $32.12 \pm 0.28$ ) (Figs. $3 \mathrm{~b}$ and $4 \mathrm{~b}$; Table 1). Similar salinity ranges for the outer shelf/slope and UP regions indicate the common source (Alaskan Stream) of these waters but lower salinity values of the ACW in the UP region suggest dilution from coastal runoff such as from the Aleutian Islands. A lens of low salinity $(\sim 30.1)$ was observed in surface waters in the middle shelf between $\sim 60-62^{\circ} \mathrm{N}$ (Fig. 3b).

Trends in surface and subsurface DOC values (Figs. 3d and $4 \mathrm{~d}$ ) showed similarities to those of the water column with elevated values in the inner shelf $(92.67 \pm 14.60 \mu \mathrm{M})$, decreasing in the middle shelf $(78.38 \pm 10.64 \mu \mathrm{M})$ and increasing in the productive outer shelf/slope region $(79.24 \pm 18.00 \mu \mathrm{M})$ of the "green belt". CDOM absorption $a_{\mathrm{g}} 355$ was relatively high in the inner shelf region around the Nunivak Islands that extended out into the middle shelf (Figs. 3e and 4e). These high CDOM (low $S$ ) waters were likely of terrestrial origin due to larger summer flow from the Kuskokwim River. Outside of this high CDOM cold water surface lens, CDOM decreased considerably and then increased slightly at some stations in the outer shelf/slope waters. Surface spectral slope $S$ (Fig. 3f) was generally high except at the mixed inner shelf. Strong summer stratification coupled with increasing solar radiation likely contributed to the enhanced photodegradation of these waters. Some of the highest $S$ values were observed in the surface waters along the northernmost SL transect probably a consequence of late ice melt, stronger stratification/reduced mixing and longer exposure to solar radiation (Fig. 3f).

At the subsurface where the Chl maxima was located, mid-1 depth Chl was low over the inner shelf but high in the middle shelf with highest values recorded just below the surface mixed layer in the northern region of the middle shelf (Fig. 4c). Values were also elevated at some outer shelf stations located in the productive "green belt" region. Subsurface CDOM absorption (Fig. 4e) was highest in the inner shelf and generally elevated in the middle shelf and decreasing in the outer shelf. It was elevated at one station in the slope region (station $\mathrm{np} 15$ ) where $\mathrm{Chl}$ was also elevated and likely an algal bloom station (Fig. 4c). This station also showed a low spectral slope $S$ suggesting recent CDOM production (Stedmon et al., 2011). Subsurface spectral slope $S$ was only slightly lower than surface waters over the inner self (Figs. $3 \mathrm{f}$ and $4 \mathrm{f}$ ), reflecting greater mixing in this region. Although surface $\mathrm{Chl}$ in the inner shelf was elevated (Fig. 3c), subsurface spatial patterns of low $\mathrm{Chl}$ matched the high CDOM distribution pattern suggesting light limitation in the inner shelf. Outside the high CDOM region, subsurface Chl was substantially higher suggesting that photobleached surface CDOM allowed greater light penetration resulting in the subsurface algal blooms.

Overall, in the middle shelf, subsurface spectral slope $S$ (Fig. 4f) was significantly lower $\left(23.72 \pm 1.58 \mu^{-1}\right)$ than in surface waters $\left(26.87 \pm 2.39 \mu \mathrm{m}^{-1} ; p<0.001\right)$. In the subsurface middle shelf $S$ was higher in the southern middle shelf $\left(<59^{\circ} \mathrm{N}\right)$ likely due to greater photodegradation associated with earlier sea-ice retreat and mixing following summer storms. 

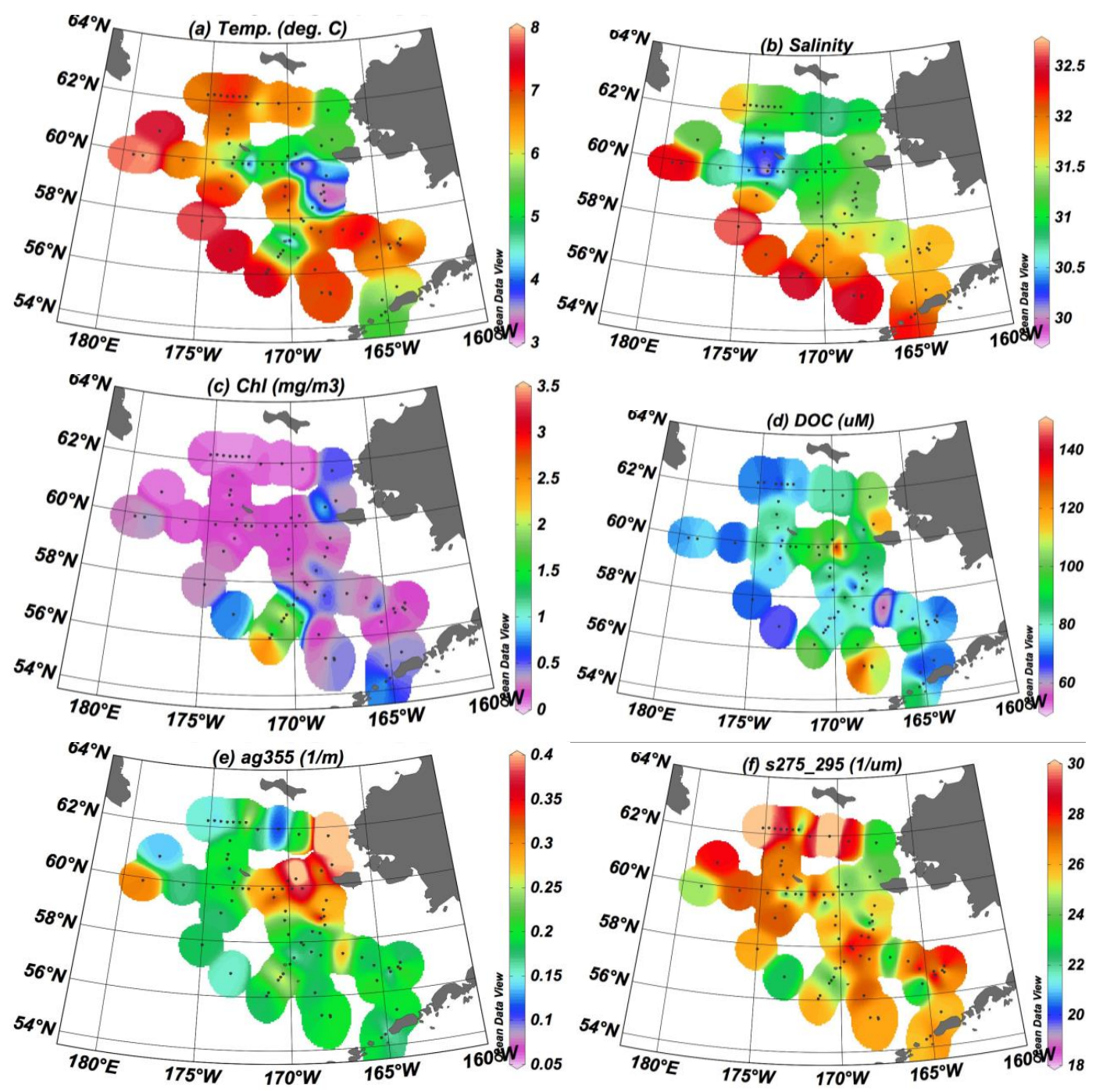

Figure 3. Spatial distributions of (a) temperature, (b) salinity, (c) Chl, (d) DOC, (e) $a_{\mathrm{g}} 355$, and (f) $S$ or $S_{275-295}$ at surface ( 2 m depth) over the study area.

\subsubsection{Vertical variability along transects}

Vertical distributions of temperature, salinity, Chl, DOC and the absorption properties were examined along two transects, the northernmost SL and the $70 \mathrm{~m}$ isobath north-south transect through the middle shelf (Figs. 1, 5 and 6). Hydrography along the SL cross-shelf transect revealed a two-layer density structure with a relatively warm surface mixed layer $(\sim 20 \mathrm{~m})$ (Fig. 5a) of lower salinity with fresher waters over the inner shelf and the eastern part of the transect (Fig. 5b). The warm surface waters transitioned into a subsurface pool of cold $\left(<0{ }^{\circ} \mathrm{C}\right)$ and more saline waters that has been attributed to brine rejection (Stabeno et al., 2012a) (Fig. 5a-b). Chl values along the transect (Fig. 5c) were very low at the surface but increased in subsurface waters revealing the presence of a large subsurface algal bloom. DOC concentrations were elevated in the inner shelf and generally decreased off- shore (Fig. 5d). A patch of elevated DOC at the near-bottom was in close proximity but not coincident with a high $\mathrm{Chl}$ patch. $a_{\mathrm{g}} 355$ was high in the inner shelf decreasing offshore and was lowest in the surface waters (Fig. 5e). A lens of low salinity surface waters with low $a_{\mathrm{g}} 355\left(0.11 \mathrm{~m}^{-1}\right)$ and very high $S\left(32.73 \mu \mathrm{m}^{-1}\right)$ (Fig. 5e and f; $\sim 171^{\circ} \mathrm{W}$ ), likely a melt pond, suggested accelerated photodegradation of the low CDOM melt water. Elevated values of CDOM were observed at depths corresponding to the Chl maximum in the subsurface waters suggesting an authochthonous source of CDOM. Except within the inner shelf, some of the highest $S$ values were observed in the surface waters and coincident with the warm surface mixed layer (Fig. 5f).

The north-south $70 \mathrm{~m}$ transect that extended through the middle shelf revealed highly stratified warm surface waters (mean $6.28 \pm 0.98^{\circ} \mathrm{C}$ ) overlying subsurface cold pool waters $\left(<2{ }^{\circ} \mathrm{C}\right)$ that occupied the entire middle shelf with 

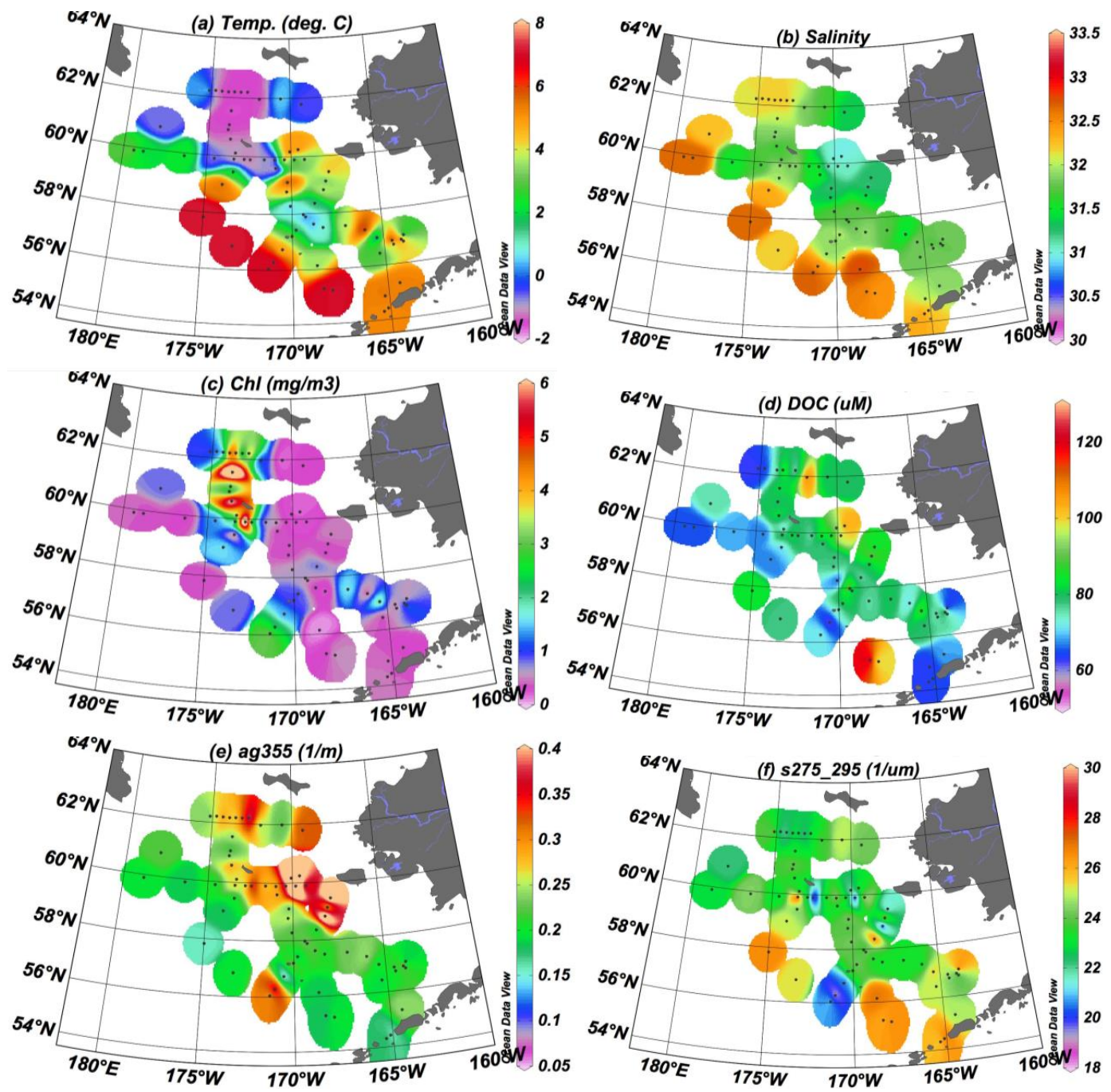

Figure 4. Spatial distributions of (a) temperature, (b) salinity, (c) Chl, (d) DOC, (e) $a_{\mathrm{g}} 355$, and (f) $S$ at mid-1 depths ( $\left.\sim 28 \mathrm{~m}\right)$ corresponding to the Chl maxima.

progressively colder waters along latitudinal gradients to the north (mean $0.81 \pm 2.62^{\circ} \mathrm{C}$ at mid-1 depth) (Fig. 6a). The density stratification was weaker in the southern part of the shelf and appeared to be determined more by temperature than by salinity (Fig. 6a and b). Salinity in the cold pool also showed an increasing trend with highest salinity values in the northern middle shelf, likely due to brine rejection (Fig. 6b). Isopycnal patterns along the $70 \mathrm{~m}$ section also suggest strong vertical mixing along the latitudinal transect likely from storms as the sea ice retreated. Elevated $\mathrm{Chl}$ was measured in the shallower subsurface $(\sim 20 \mathrm{~m})$ waters in the southern part of the middle shelf (Fig. 6c), that was more intense and in deeper $(\sim 40 \mathrm{~m})$ waters in the northern part of the shelf. DOC concentrations showed no clear trends in distribution across the transect (Fig. 6d) while CDOM absorption $a_{\mathrm{g}} 355$ showed trends along the isopycnals (Fig. 6e). In contrast, the spectral slope $S$ was clearly higher in the warm surface mixed layer than in the underlying cold pool waters (Table 1). Within the cold pool, higher $S$ in the southern shelf suggests the increased exposure of these waters to solar radiation and mixing of the water column as the sea ice retreated.

\subsection{CDOM fluorescence properties}

\subsubsection{Fluorescence components from PARAFAC analysis}

PARAFAC analysis identified five major fluorescence components from approximately 174 EEMs spectra of water samples from the eastern Bering Sea (Fig. 7; Table 2). The excitation and emission loadings of each of the five components identified using the PARAFAC model are shown in Fig. 7 (bottom right panel). Component $1(\mathrm{C} 1)$ has a primary (and secondary) fluorescence peak at an excitation and emission wavelength of $<260(310) / 410 \mathrm{~nm}$. This component has 
Table 2. Description of the five components identified by PARAFAC analysis of EEMs fluorescence data in this study and their comparison with previously identified components.

\begin{tabular}{|c|c|c|c|c|}
\hline Comp. & $\begin{array}{l}\text { Excitation } \\
\text { maxima }(\mathrm{nm})\end{array}$ & $\begin{array}{l}\text { Emission } \\
\text { Maxima (nm) }\end{array}$ & Description & References \\
\hline $\mathrm{C} 1$ & $<260(310)$ & 410 & $\begin{array}{l}\text { Marine humic-like component } \\
\text { Biological and/or microbial origin }\end{array}$ & $\mathrm{M}^{\mathrm{a}}, \mathrm{C} 4^{\mathrm{b}}, \mathrm{C} 3^{\mathrm{c}}, \mathrm{C}^{\mathrm{d}}$ \\
\hline $\mathrm{C} 2$ & $<260(400)$ & 475 & Terrestrial humic-like & $\mathrm{A}^{\mathrm{a}}, \mathrm{C} 3^{\mathrm{b}}, \mathrm{C} 2^{\mathrm{c}}, \mathrm{C} 4^{\mathrm{e}}, \mathrm{C} 1^{\mathrm{f}}$ \\
\hline $\mathrm{C} 3$ & 270 & 310 & Tyrosine-like, protein-like & $\mathrm{B}^{\mathrm{a}}, \mathrm{C} 5^{\mathrm{c}}, \mathrm{C} 7^{\mathrm{d}}, \mathrm{C} 5^{\mathrm{e}}, \mathrm{C} 5 \mathrm{f}$ \\
\hline $\mathrm{C} 4$ & 285 & 330 & Tryptophan-like, protein-like & $\mathrm{T}^{\mathrm{a}}, \mathrm{C} 5^{\mathrm{b}}, \mathrm{C} 5^{\mathrm{e}}, \mathrm{C} 3^{\mathrm{f}}$ \\
\hline C5 & 360 & 455 & $\begin{array}{l}\text { Fulvic-like, present in all environments, } \\
\text { autochthonous/terrestrial }\end{array}$ & $\mathrm{C}^{\mathrm{a}}, \mathrm{C} 2^{\mathrm{b}}, \mathrm{C} 4^{\mathrm{c}}$ \\
\hline
\end{tabular}

${ }^{\mathrm{a}}$ Coble (1996), ${ }^{\mathrm{b}}$ Stedmon et al. (2003), ${ }^{\mathrm{c}}$ Stedmon and Markager (2005b), ${ }^{\mathrm{d}}$ Yamashita et al. (2008), ${ }^{\mathrm{e}}$ Kowalczuk et al. (2009), ${ }^{\mathrm{f}}$ Guegen et al. (2012).
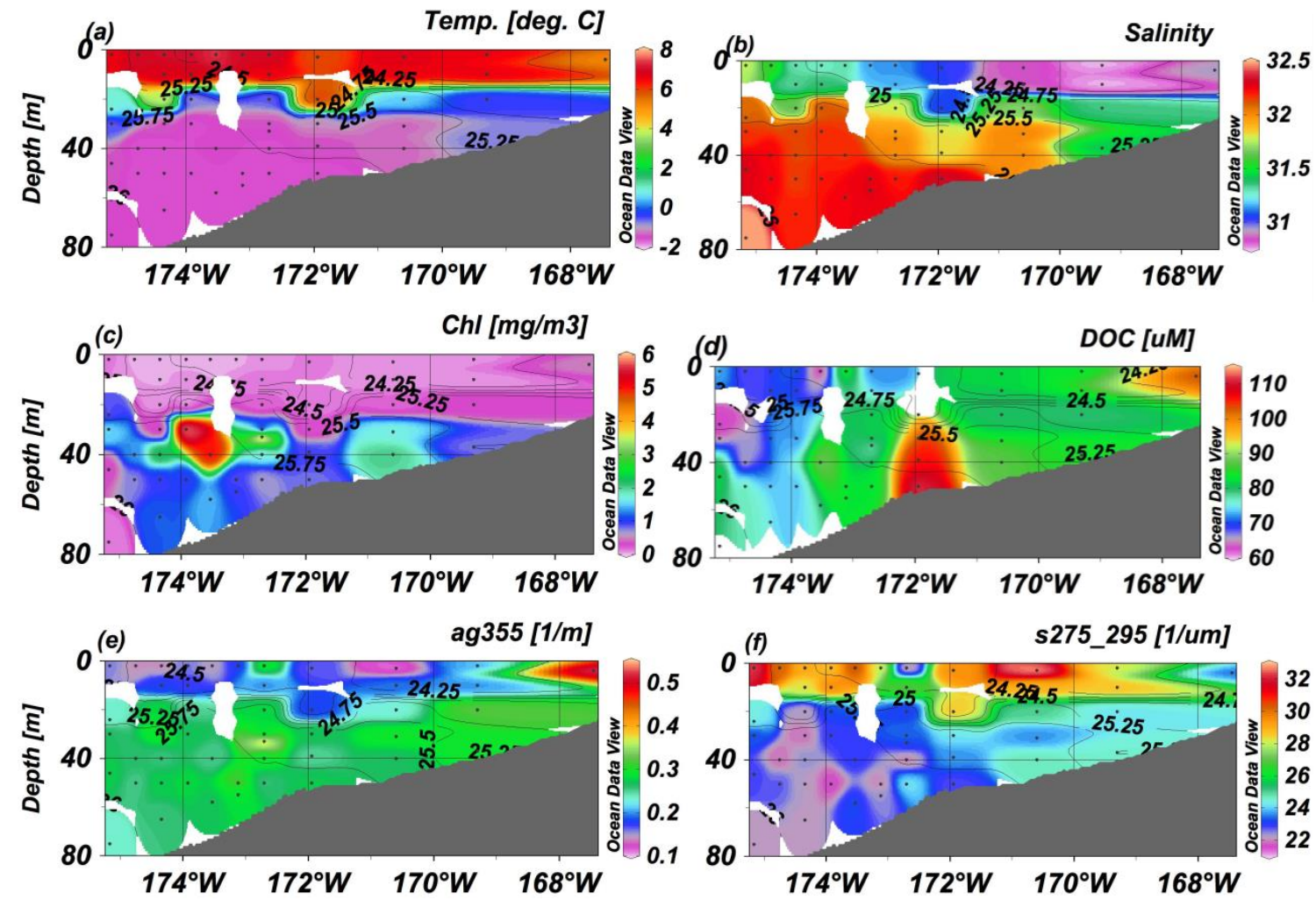

Figure 5. Vertical section of (a) temperature, (b) salinity, (c) Chl, (d) DOC, (e) $a_{\mathrm{g}} 355$, and (f) $S_{275-295}$ along SL transect with overlain contour lines of density.

been previously identified as "M" or marine humic-like component and is of biological and/or microbial origin (Coble, 1996; Stedmon et al., 2003, 2005b; Yamashita et al., 2008). It may result from biological activity and/or microbial reworking of plankton-derived DOM (Yamashita et al., 2008) and was found to be both sourced from land and produced in the ocean (Murphy et al., 2008). The fluorescence peaks of component $2(\mathrm{C} 2)$ at excitation/emission wavelengths of $<260(400) / 475 \mathrm{~nm}$ is similar to previously identified terrestrial humic-like material or "A" peak (Coble, 1996; Sted- mon et al., 2003, 2005b; Gueguen et al., 2012; Walker et al., 2009). Fluorescence of components 3 (C3) and 4 (C4) are of proteinaceous origin, namely tyrosine and tryptophan. Excitation/emission peaks of tyrosine-like fluorescence were identified at 270/310 nm and for tryptophan-like fluorescence at 285/330 nm (Stedmon et al., 2003, 2005b; Yamashita et al., 2008; Kowalczuk et al., 2009; Gueguen et al., 2012) and are similar to previously reported B- and T-peaks identified using "peak-picking" technique (Coble, 1996). Component 5 (C5) with excitation/emission wavelengths of $360 / 455 \mathrm{~nm}$ is 

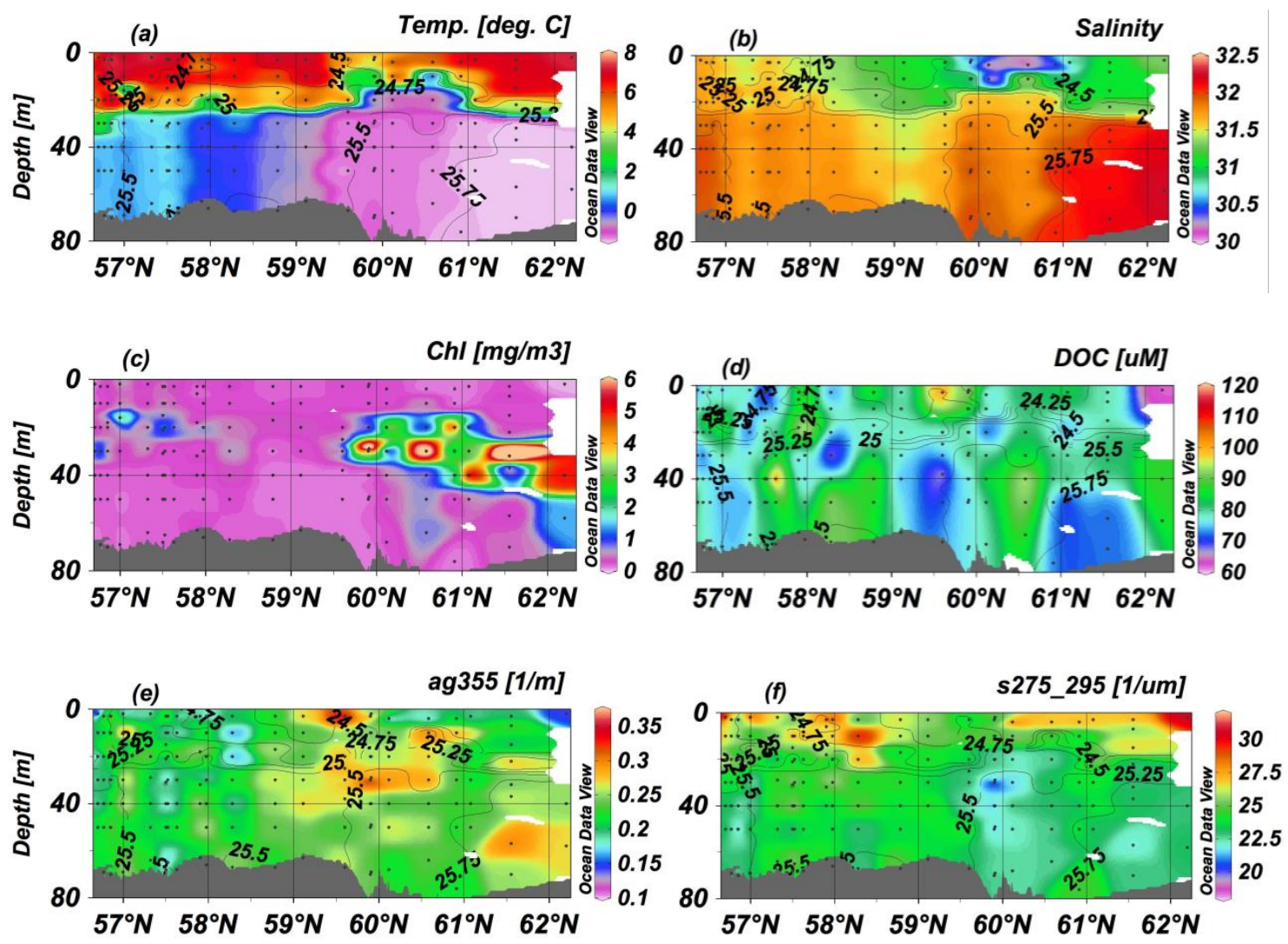

Figure 6. Vertical section of (a) temperature, (b) salinity, (c) Chl, (d) DOC, (e) $a_{\mathrm{g}} 355$, and (f) $S_{275-295}$ along $70 \mathrm{~m}$ transect with overlain contour lines of density.

similar to the previously reported "C" peak (Coble, 1996). This fulvic-like fluorophore has been observed in all environments that include terrestrial, coastal and oceanic waters (Stedmon et al., 2003, 2005b, Murphy et al., 2008; Kowalczuk et al., 2009). The following section describes the distribution of five major types of fluorophores identified by PARAFAC.

\subsubsection{Fluorescent DOM components and hydrography}

Firstly, the fluorescent DOM components are examined in relation to salinity, temperature, CDOM absorption, and slope $S$ (Fig. 8). Although mean component concentrations differed for the different regions (Table 3), the marine humic-like component $\mathrm{C} 1$ was the most dominant fluorophore (Table 3, Fig. 8a), while the protein-like tyrosinelike component $\mathrm{C} 3$ plus the tryptophan-like component $\mathrm{C} 4$ formed the second most abundant group of fluorophores. Within the low salinity waters $(<31.3)$, the fluorescence intensities of sea ice meltwaters were lower than the riverinfluenced inner shelf waters with humic-like material showing decreasing but not significant trend with increasing salinity. Humic-like components $\mathrm{C} 1, \mathrm{C} 2$ and C5 were generally higher in the coldest waters decreasing with increasing tem- perature from about -2 to $4{ }^{\circ} \mathrm{C}$ (Fig. 8b). These elevated levels were mainly associated with $<2{ }^{\circ} \mathrm{C}$ waters of the cold pool in the northern part of the middle shelf that gradually decreased southwards. Fluorescence of protein-like components $\mathrm{C} 3$ and $\mathrm{C} 4$ were quite variable revealing no particular trends with temperature. Mean component intensities C1-C5 (0.54 $\pm 0.10,0.30 \pm 0.06,0.37 \pm 0.12,0.19 \pm 0.11$, and $0.26 \pm 0.11$ R.U., respectively) of the UP region in addition to being the highest of the study region, also contained the highest relative percentage $(21.9 \%)$ of tyrosinelike fluorophore (Table 3 ) indicative of more degraded amino acid pool in the water column. These waters associated with the $\mathrm{ACW}$, which were generally constrained within a narrow salinity $(\sim 32-32.5)$ and temperature $\left(\sim 5^{\circ} \mathrm{C}\right)$ range (Fig. $8 \mathrm{a}$ and $b$ ), had very low absorption that deviated from the general trend of increasing fluorescence with increasing absorption (Fig. 8c; as represented by values within the ellipse).

Correlations between the humic-like fluorescence components and absorption were significant $(p<0.0001)$ for the middle shelf with the marine-like $\mathrm{C} 1$ component better correlated $\left(r^{2}=0.42\right)$, than the $\mathrm{C} 2\left(r^{2}=0.38\right)$ and $\mathrm{C} 5\left(r^{2}=\right.$ $0.40)$ components. However, the protein-like fluorophores were not correlated with $a_{\mathrm{g}} 355$ (Fig. 8c). All the humic-like components were negatively correlated with spectral slope 

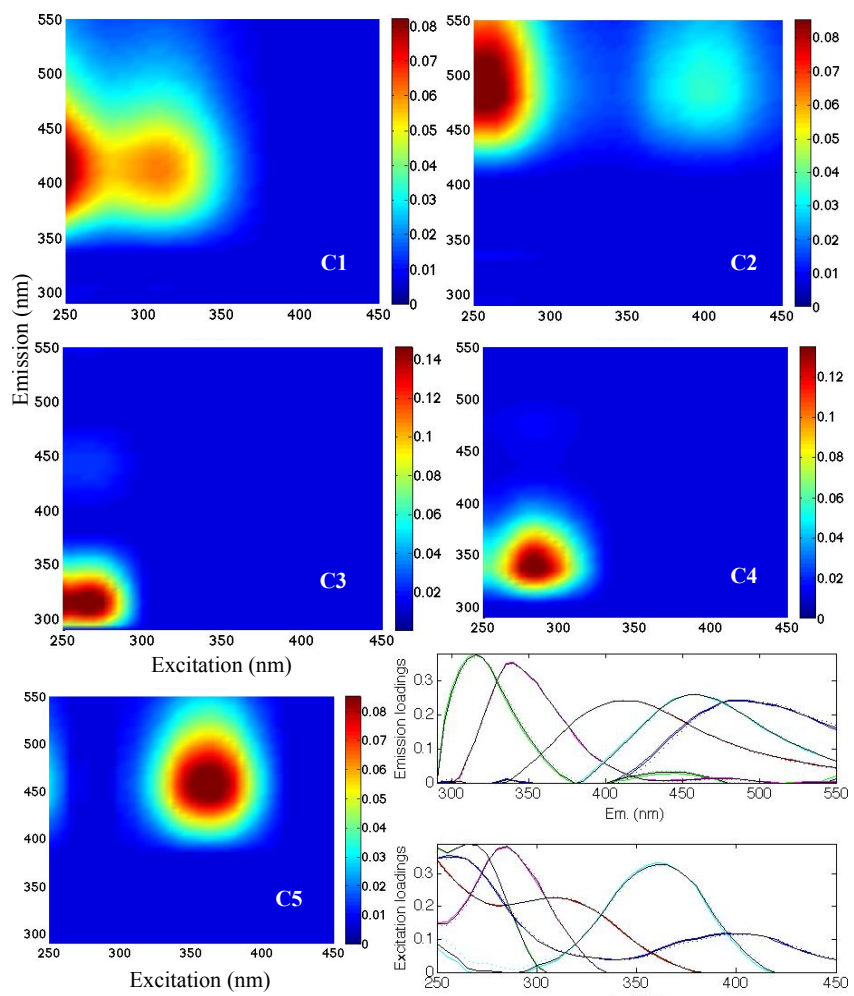

Excitation (nm)

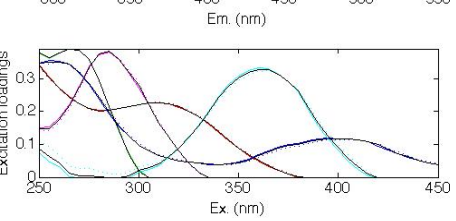

Figure 7. Spectral characteristics of the five fluorescent components (C1, C2, C3, C4, and C5) identified by PARAFAC. Figures show the EEMs plots of individual components in Raman Units (R.U.) of intensity. Excitation and emission loadings derived from the fivecomponent PARAFAC model using split-half validation technique (bottom right). Dashed, colored solid and black lines represent the excitation and emission loadings of the two split halves and the whole data set, respectively. Positions of their maxima are given in Table 2.

$S$ in the middle shelf (Fig. 8d) with $\mathrm{C} 1$ showing the largest negative but significant trend (slope $=-0.015, r^{2}=0.42$, $p<0.0001)$. The $S$ correlations with protein-like components however were not significant although a slight negative trend can be observed (Fig. 8d).

\subsubsection{Horizontal spatial variability}

Surface spatial patterns of variability in humic-like components $\mathrm{C} 1, \mathrm{C} 2$, and $\mathrm{C} 5$ revealed similar patterns of distribution, being highest in the inner shelf and in the UP region and generally decreasing towards the middle and outer shelves (mean $0.45 \pm 0.13,0.24 \pm 0.07,0.12 \pm 0.05$ R.U., and $0.28 \pm 0.0 .06,0.15 \pm 0.02,0.09 \pm 0.02$ R.U., within the inner and middle shelves, respectively) (Table 3) (Fig. 9a, $\mathrm{b}$ and e). These values correspond to $41.2,21.9,11.6 \%$, and $37.7,19.9,11.5 \%$, respectively of the total fluorophores in the two shelves. Similar relative concentrations of these components were observed in the outer shelf/slope region of the Bering Sea (Table 3). Patterns of protein-like com-
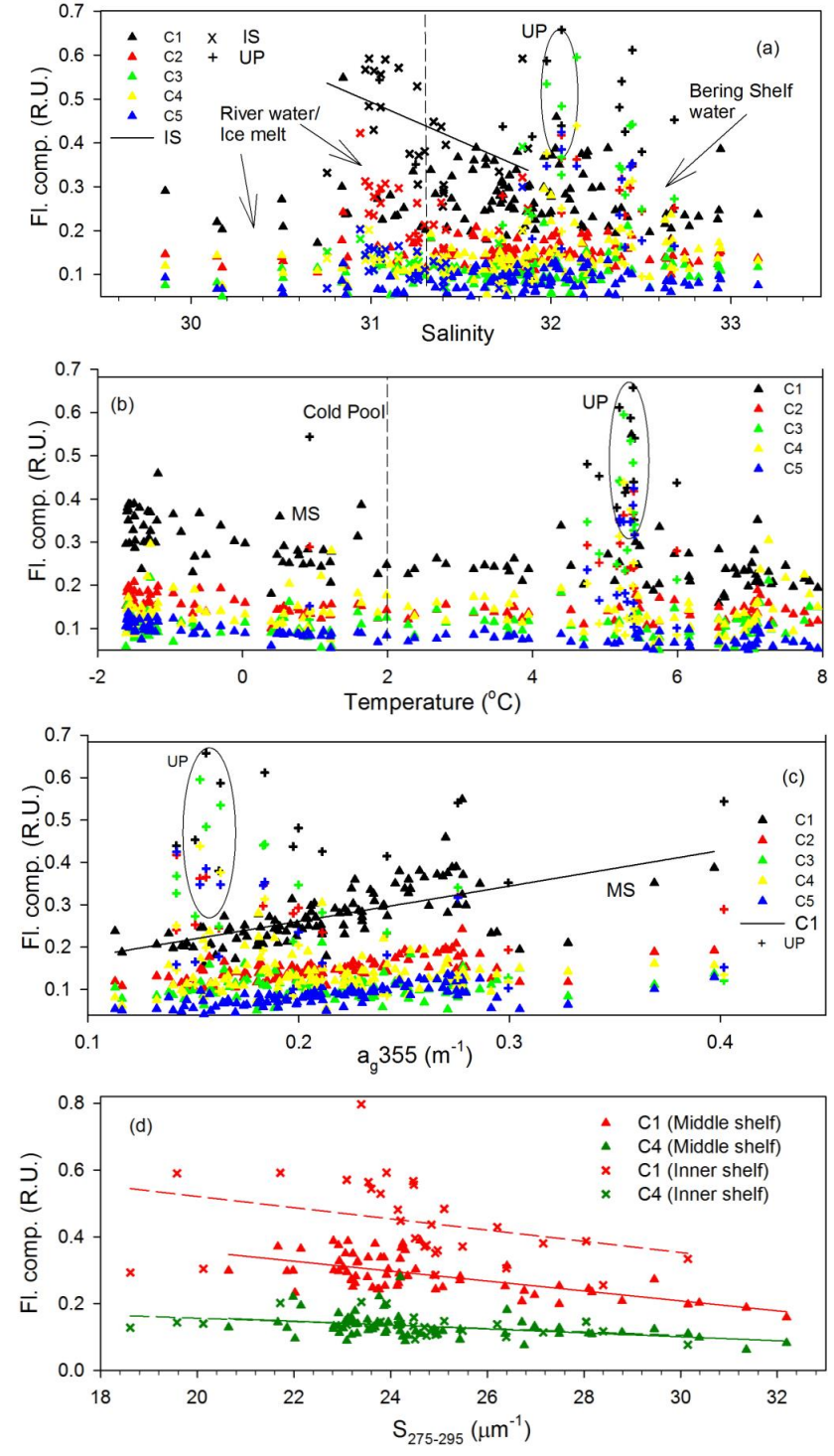

Figure 8. Relationships between (a) salinity (b) temperature, (c) $a_{\mathrm{g}} 355$, and (d) $S_{275-295}$ and the fluorescence components C1, C2, C3, C4, and C5. Triangles are for data from the middle and outer shelf/slope, $x$ for the inner shelf (IS), and + for the Unimak Pass (UP) region.

ponents however differed from the humic-like components and at different locations (Fig. 9c and d). The tyrosine-like component $\mathrm{C} 3$ was more elevated in the inner shelf region $(0.14 \pm 0.06$ R.U. $)$ while the tryptophan-like component C4 was elevated $(0.16 \pm 0.05$ R.U.) in the outer shelf/slope region forming 13.1 and $22.1 \%$, respectively of the more degraded and fresher fraction of the amino acid pool in the two regions. However, the tryptophan-like $\mathrm{C} 4$ component which represents the fresher fraction of the amino-acids in DOM was more elevated within the productive cold pool of the middle shelf than the inner shelf. Highest values of proteinlike $\mathrm{C} 3$ and $\mathrm{C} 4$ fluorophores were however in the UP region 
Table 3. Mean of the five fluorescence components identified by the PARAFAC model in the different regions (IS-inner shelf, MS-middle shelf, OS + SL-outer shelf/slope, UP-Unimak Pass) of the Bering Sea. In addition, in the middle shelf mean values of fluorescence components at surface (MS-s), mid-1 (MS-1) and mid-2 (MS-2) depths are also shown. Percentage compositions of the components are given for each of the regions.

\begin{tabular}{lcccccccccc}
\hline region & $\mathrm{C} 1$ & $\mathrm{C} 2$ & $\mathrm{C} 3$ & $\mathrm{C} 4$ & $\mathrm{C} 5$ & $\% \mathrm{C} 1$ & $\% \mathrm{C} 2$ & $\% \mathrm{C} 3$ & $\% \mathrm{C} 4$ & $\% \mathrm{C} 5$ \\
\hline UP & $0.54 \pm 0.1$ & $0.30 \pm 0.06$ & $0.37 \pm 0.12$ & $0.19 \pm 0.11$ & $0.26 \pm 0.11$ & 32.5 & 18.1 & 21.9 & 11.7 & 15.8 \\
IS & $0.45 \pm 0.13$ & $0.24 \pm 0.07$ & $0.14 \pm 0.06$ & $0.13 \pm 0.03$ & $0.12 \pm 0.05$ & 41.2 & 21.9 & 13.1 & 12.3 & 11.6 \\
MS & $0.28 \pm 0.06$ & $0.15 \pm 0.02$ & $0.10 \pm 0.03$ & $0.13 \pm 0.04$ & $0.09 \pm 0.02$ & 37.7 & 19.9 & 13.5 & 17.3 & 11.5 \\
MS-s & $0.24 \pm 0.07$ & $0.14 \pm 0.03$ & $0.09 \pm 0.03$ & $0.11 \pm 0.02$ & $0.06 \pm 0.02$ & 37.2 & 20.9 & 15.2 & 16.5 & 10.1 \\
MS-1 & $0.31 \pm 0.06$ & $0.16 \pm 0.03$ & $0.11 \pm 0.03$ & $0.14 \pm 0.04$ & $0.10 \pm 0.01$ & 37.4 & 19.6 & 13.4 & 17.7 & 11.7 \\
MS-2 & $0.31 \pm 0.07$ & $0.16 \pm 0.04$ & $0.11 \pm 0.06$ & $0.14 \pm 0.05$ & $0.10 \pm 0.04$ & 37.5 & 19.6 & 13.5 & 16.9 & 12.5 \\
OS+SL & $0.23 \pm 0.23$ & $0.14 \pm 0.02$ & $0.12 \pm 0.03$ & $0.16 \pm 0.05$ & $0.08 \pm 0.07$ & 32.2 & 18.9 & 16.1 & 22.1 & 10.6 \\
\hline
\end{tabular}

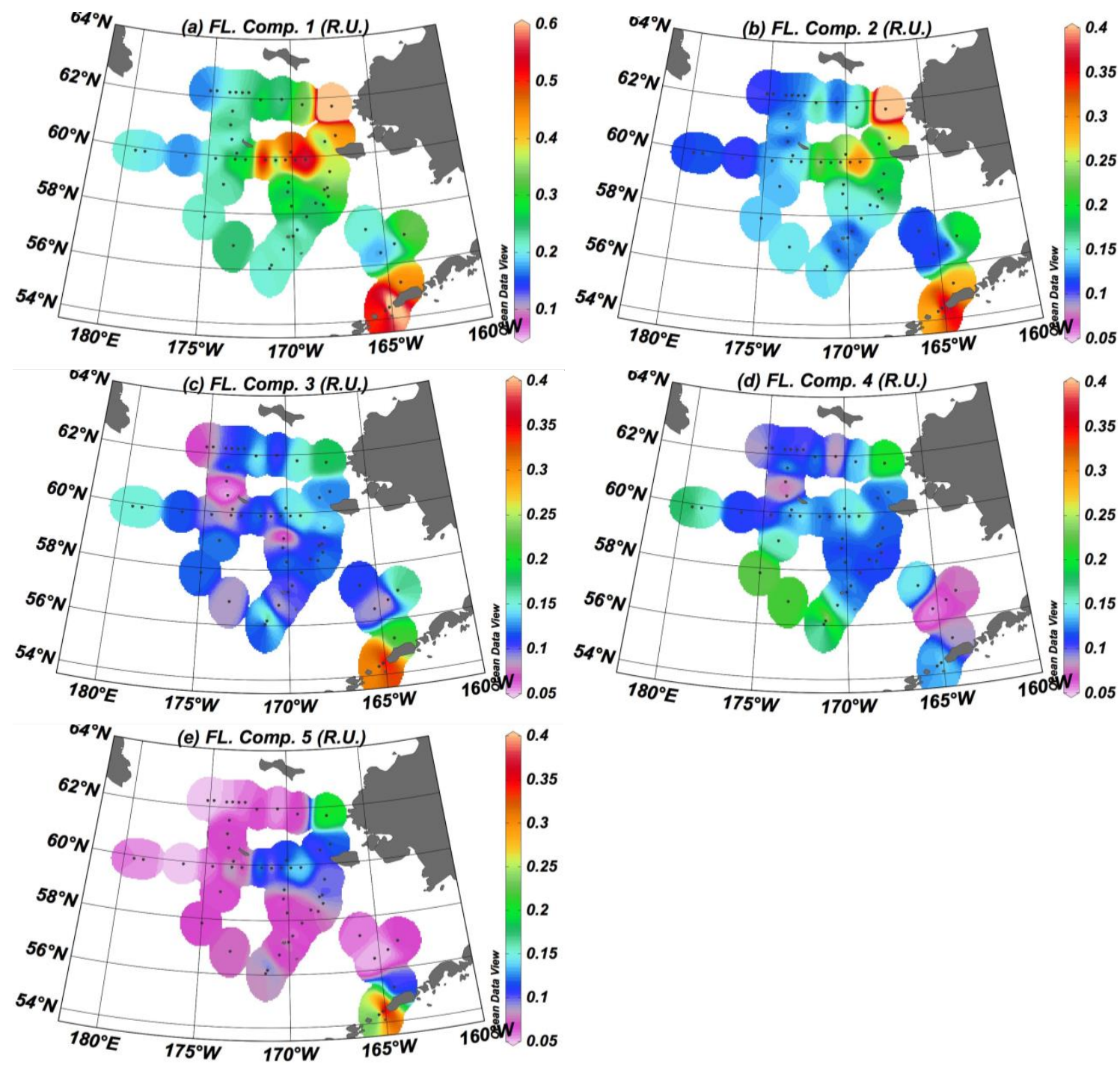

Figure 9. Spatial distributions of (a-e) fluorescence components C1-C5, of surface waters. 
suggesting the presence of both fresh and degraded amino acids in the region (Table 3).

\subsubsection{Vertical variability along transects}

The cross-shelf vertical variability of the fluorescent components along the northern-most SL transect show clear differences between the humic-like and protein-like components (Fig. 10a-e). The distribution of the humic-like components $\mathrm{C} 1, \mathrm{C} 2$, and C5 (Fig. 10a, b, and e) generally showed a pattern of decreasing intensity from the inner shelf into the middle shelf while lower intensities of the humic-like components in the surface mixed layer in comparison to the underlying cold pool suggested photodegradation of these fluorophores. The protein-like components $\mathrm{C} 3$ and $\mathrm{C} 4$ while elevated in the inner shelf showed a more complex pattern offshore (Fig. 10c and d). AOU was found to be elevated within the high salinity cold bottom waters (Fig. 10f) High negative AOU values were observed at depths corresponding to elevated Chl concentrations (Figs. 10f and 5c).

Along the $70 \mathrm{~m}$ line, contrasting patterns were observed between the humic-like and protein-like components (Fig. 11a-e). The humic-like components $\mathrm{C} 1, \mathrm{C} 2$, and C5 revealed clear distinction in component intensity between the surface mixed layer and the subsurface cold pool waters through most of the middle shelf. Transitions in temperature or salinity (Fig. 6a and b) along the transect within the cold pool appeared to coincide with patterns of varying humic-like component intensities (Fig. 11a, b and e) suggesting strong linkages between the physical properties and the humic-like fluorescence components. In the case of the protein-like components $\mathrm{C} 3$ and $\mathrm{C} 4$, there were no clear trends within the cold pool or the surface mixed layer although the $\mathrm{C} 4$ tyrosine-like component appeared elevated at the subsurface $\mathrm{Chl}$ maximum suggesting the presence of increased fresh organic material (Fig. 11c and d). AOU was negative along the surface mixed layer along the whole transect that decreased further in the northern shelf at depth corresponding to the $\mathrm{Chl}$ maxima (Fig. 11f). AOU within the cold pool was overall positive increasing northwards showing variation along the vertical isopycnals.

\section{Discussion}

\subsection{DOM characteristics in the eastern Bering Sea and the cold pool region}

Patterns of absorption and fluorescence observed in the eastern Bering Sea suggest a combination of both allochthonous and authochthonous origins of CDOM. The values of absorption coefficients (e.g., $a_{\mathrm{g}} 355$ ) observed in the eastern Bering Sea were generally lower than those reported for the western Arctic Ocean shelf region influenced by the McKenzie River (Gueguen et al., 2005$)$ and comparable to values $(\sim 0.2$ to $0.3 \mathrm{~m}^{-1}$ ) reported for the shelf break region of the mid-
Atlantic Bight (Del Vecchio and Blough, 2004). The DOC concentrations were similar to those reported for the summer in the Chukchi Sea shelf $(77 \pm 12 \mu \mathrm{M})$ (Shen et al., 2012).

Although the salinity $-a_{\mathrm{g}} 355$ relationship shows three broad trends (Fig. 2a), variations within each of the shelf regions are observed such as in the outer shelf/slope and the DBS waters where there is no significant difference in $a_{\mathrm{g}} 355$ between the DBS waters at depths $>$ and $<1000 \mathrm{~m}$ indicating no loss of CDOM with depth in this region. Overall, the spectral slope $S$ was negatively correlated with salinity which could be attributed to differences in water masses and/or to enhanced photodegradation of CDOM in the highly stratified low salinity surface ice meltwaters, and is in contrast to river-dominated systems where $S$ increases with increasing salinity (Fichot and Benner, 2012). The inverse significant relation between $S$ and salinity suggest a strong linkage between the CDOM optical property and hydrography and could be used as a tracer of water mass especially in the DBS. $S$ was also low at the inner shelf and stations located near the various islands in the eastern Bering Sea suggesting higher molecular weight and greater aromaticity of the dissolved material.

The inverse spectral slope $S-a_{\mathrm{g}} 355$ relationship (Fig. 2c) distinguished the different water masses in the eastern Bering Sea that were modeled using nonlinear regression equations with the terrestrial and oceanic end members showing similar patterns to that developed for the Greenland and North Sea (Stedmon and Markager, 2001). The model for the middle shelf (line 2, Fig. 2c) which lies between the terrestrial and oceanic model trends more towards the inner shelf model reflecting the terrestrial influence associated with strong winter mixing of the water masses; a larger gradient in the $S_{-}$ $a_{\mathrm{g}} 355$ relationship appears to be due to enhanced photooxidation of surface waters and mixing with the outer shelf waters. The outer shelf/slope waters which extends over a large region of the eastern Bering shelf and includes the productive green belt region and the St. Paul and Pribilof Islands shows a broad scatter in the $S$ - $a_{\mathrm{g}} 355$ property relationship which is however weighted towards the oceanic end member. The UP region model (line 3, Fig. 2c) at low $a_{\mathrm{g}} 355$ appeared to show oceanic properties but exhibited terrestrial trends with increasing absorption likely reflecting the influence of enhanced runoff from the Aleutian Islands during the summer. The sea ice water mass showed a trend similar to the inner shelf that was however shifted upwards indicating higher photodegration of these waters. These results indicate that the $S-a_{\mathrm{g}} 355$ behavior could be used to differentiate the water masses based on the CDOM optical properties in the eastern Bering Sea.

High inverse correlation between AOU an indicator of microbial remineralization and $S\left(r^{2}=0.79\right)$ with $a_{\mathrm{g}} 355$ not significantly different in the deep Bering Sea waters $(>1000 \mathrm{~m})$ from the waters above, strongly suggests oxidation of organic matter that is of increasingly higher molecular weight with depth/age of the water mass (Nelson et al., 

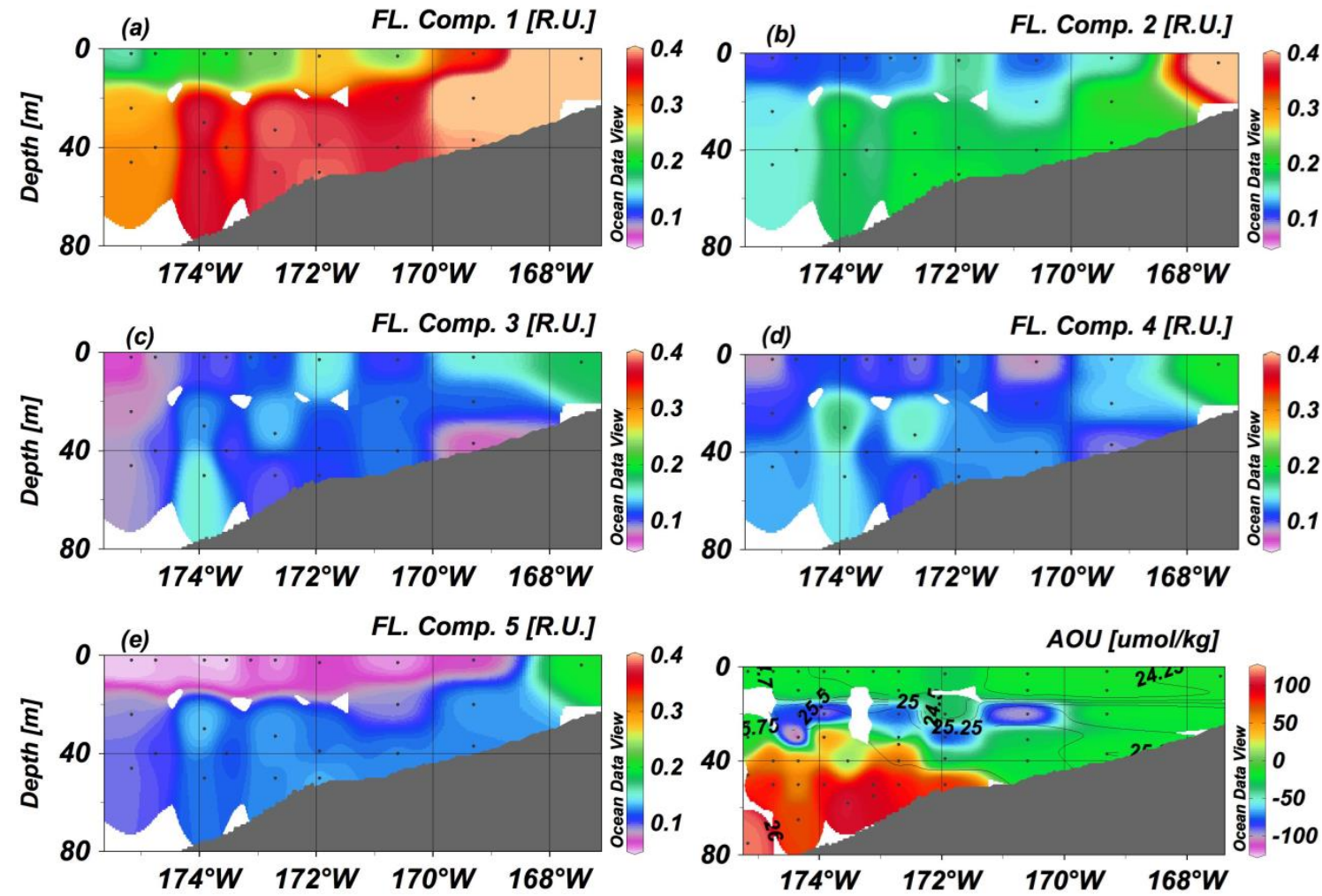

Figure 10. Vertical section of (a-e) fluorescence components C1-C5, and (f) AOU along the SL transect.
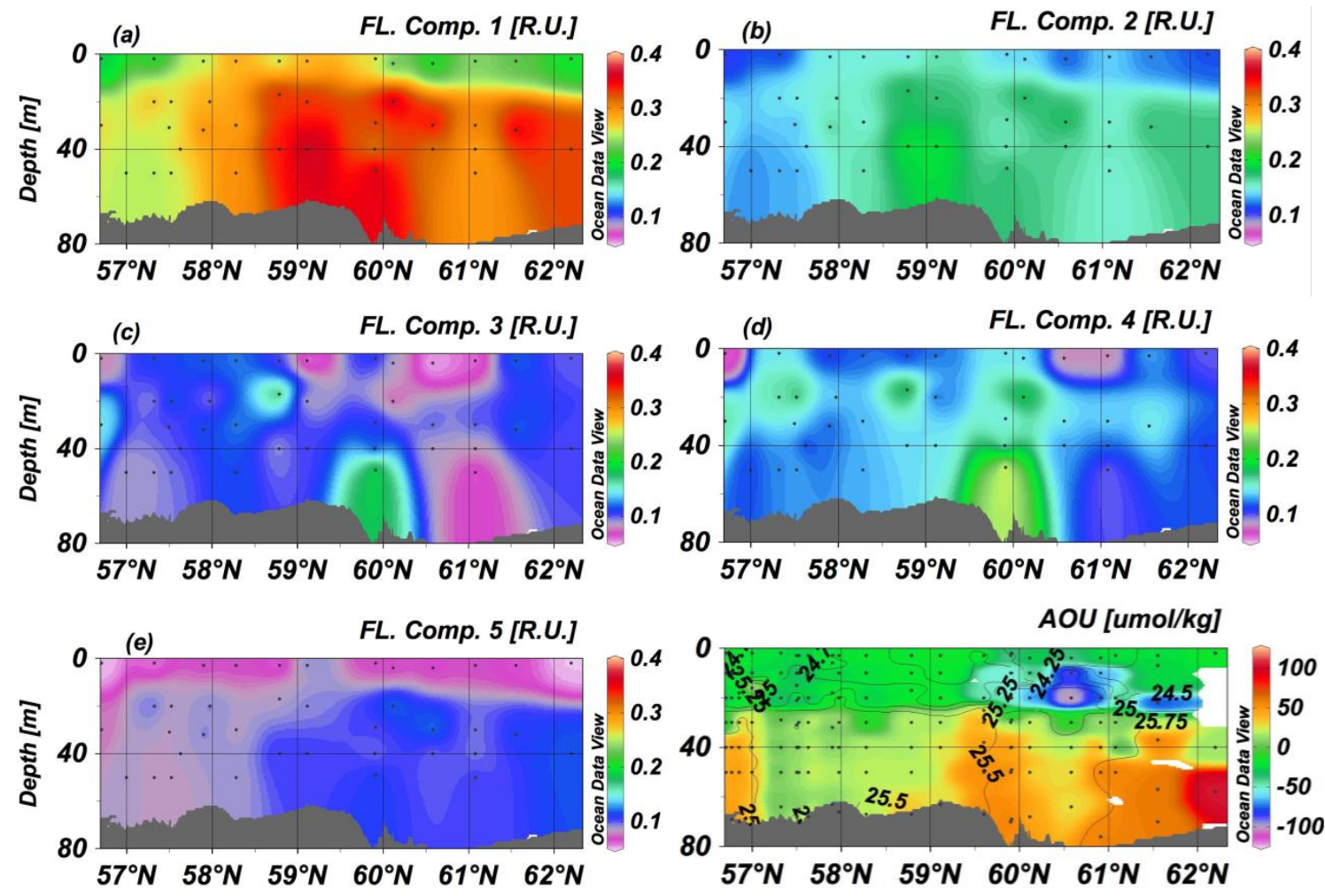

Figure 11. Vertical section of (a-e) fluorescence components $\mathrm{C} 1-\mathrm{C} 5$, and (f) AOU along the $70 \mathrm{~m}$ transect. 
2010; Helms et al., 2008). A strong relationship between $S$ and nitrate $\left(r^{2}=0.63\right)$ also supports the link between the CDOM optical properties and the microbial remineralization of likely more refractory organic material with depth/age. The high AOU values in the deep slope Bering Sea waters also indicate these waters to be even older than previously reported for the northern Pacific (Nelson et al., 2010) with likely more refractory DOM material. Elevated AOU values in the northern middle shelf waters (Figs. 10f and 11f) corresponded to elevated salinity in the cold pool, low $S$ and slightly elevated $a_{\mathrm{g}} 355$ (Figs. 5e, f and 6e, f) likely the effects of brine rejection during ice formation in winter and the subsequent remineralization of the organic matter in these waters (Dittmar, 2004; Granskog et al., 2012; Matsuoka et al., 2012). Elevated negative AOUs (Figs. 10f and 11f) were also observed in the northern middle shelf corresponding to elevated $\mathrm{Chl}$ that contributed to excess oxygen by primary production.

Significant correlations between CDOM absorption and humic-like fluorescence components (Fig. 8c) as well as inverse relationships between spectral slope $S$ and the humiclike fluorescence components in the middle shelf suggest similar influences on the chromophoric and humic-like fluorescence DOM. However, lack of relationship between CDOM absorption properties and protein-like fluorescence components indicate these components may not contribute much to the chromophoric pool especially in the middle shelf waters.

In the cold northern middle shelf $\left(>60^{\circ} \mathrm{N}\right)$ high subsurface phytoplankton biomass and corresponding elevated absorption that decreased in the southern middle shelf (Fig. 4c and e) strongly suggests autochthonous production of CDOM. In the highly productive section between $\sim 60$ $62^{\circ} \mathrm{N}$, the protein-like component $\mathrm{C} 3$ (tyrosine-like, more degraded amino acids) was lower while tryptophan like component C4 (fresh amino acids) was higher further supporting the likelihood of autochthonous production of fresh, labile CDOM. In the southern middle shelf $\left(<59^{\circ} \mathrm{N}\right)$ patterns of $a_{\mathrm{g}} 355$ and $S$ were more complex; elevated $a_{\mathrm{g}} 355$ and tryptophan-like $\mathrm{C} 4$ were observed at depths corresponding to elevated $\mathrm{Chl}$ (Figs. 4c, e and 11d) suggesting that fresh CDOM may be contributing to the DOM pool. The relative intensities of the components were similar at surface and subsurface depths (Table 3) suggesting that the typical fluorescence composition of the middle shelf is maintained in spite its extensive area and the variability in the sinks and sources of the CDOM. Similar humic-like and protein-like fluorophores have been identified in the western Arctic with a humic fluorophore linked to Pacific waters (Gueguen et al., 2012).

The presence of an extensive cold pool and the strong stratification that prevailed during the summer of 2008 had a strong influence on the optical properties of CDOM in the eastern Bering Sea. This was evident in the comparison of surface and subsurface waters where mean $a_{\mathrm{g}} 355$ of sur- face mixed layer was on average $17.1 \%$ lower and $S 12.7 \%$ higher than the subsurface cold pool waters. Similarly, photodegradation also affected the fluorescent components. In the surface mixed layer waters, humic-like fluorophores $\mathrm{C} 1$, $\mathrm{C} 2$, and $\mathrm{C} 5$ experienced an average loss of $\sim 22.5,12.5$, and $40.0 \%$ respectively of their fluorescent intensities. The earlier ice retreat coupled with greater solar insolation and mixing due to summer storms likely initiated earlier photodegradation of surface mixed layer in the middle shelf south of $59^{\circ} \mathrm{N}$ as indicated by the more elevated $S$ values across the water column. Although, the protein-like $\mathrm{C} 3$ and C4 were lower by 18.2 and $21.4 \%$, respectively in the surface mixed layer, patterns of distribution suggested that the differences were more related to increases in the protein-like fluorophores associated with in situ production of these fluorophores. Except along the inner shelf, much of the eastern Bering Sea surface waters appeared to be impacted by photodegradation as indicated by lower $a_{\mathrm{g}} 355$ and increased $S$. Elevated values of CDOM absorption, DOC and fluorescence observed at some locations along the $70 \mathrm{~m}$ transect suggest that CDOM could also be released from the shelf sediments (Boss et al., 2001). Bering Sea shelf sediments have been found to be a net source of DOC to the Arctic Ocean (Cooper et al., 2005) suggesting that strong tides and powerful storms that occur in the Bering Sea could introduce CDOM/DOM into the water column, which can then transported to the Arctic.

Between $59-60^{\circ} \mathrm{N}$, surface waters of the middle shelf appeared to be influenced by a lens of cooler and lower salinity waters of the inner shelf with elevated $a_{\mathrm{g}} 355$ and lower $S$ (Figs. 3 and 6). However, north of $60^{\circ}$ the water column was well delineated with lower $a_{\mathrm{g}} 355$, higher $S$ in the surface mixed layer and lower $S$ within the cold pool waters due to reduced mixing (greater surface stratification) of the water column. Photochemical degradation can be a major sink of CDOM and can change the DOM pool to low molecular weight, biologically labile compounds (Mopper and Kieber, 2002). The lower fluorescence intensities observed in surface layer of oceanic waters have been attributed to photochemical degradation, which also acts as a sink of the humic-like compounds (Jorgensen et al., 2011). The seasonal sea ice dynamics coupled with summer storms, and solar insolation appeared to have strongly influenced the CDOM photooxidative state of the waters in the eastern Bering Sea. Further, higher rates of photobleaching and thus lower light attenuation (Naik et al., 2013) could have contributed to greater light penetration resulting in massive phytoplankton blooms at greater depths of the northern middle shelf.

\subsection{DOM characteristics in the UP region}

The Unimak Pass, a relatively shallow $(<80 \mathrm{~m})$ and narrow $(\sim 30 \mathrm{~km})$ pass acts as a conduit for a portion of the Alaska Coastal Waters (ACW) into the eastern Bering Sea (Stabeno et al., 1999). Hydrographic properties measured at 
stations along the pass and on the Bering shelf side of the Unimak Island show the salinity (32.12) and temperature $\left(5.39^{\circ} \mathrm{C}\right)$ characteristics of the $\mathrm{ACW}$ which flows along the shelf and extends $\sim 1000 \mathrm{~km}$ along the Gulf of Alaska. Absorption and fluorescence properties show unique signatures that deviated from the general trend in the eastern Bering Sea. Low $a_{\mathrm{g}} 355$ and high $S$ observed in the region was likely due to greater photodegradation of the ACW as it flows along the Alaskan coast. Relatively low values of DOC, Chl and $a_{\mathrm{g}} 355$ but high fluorescent components indicate additional source such as from glacial meltwaters to the ACW. Fluorescent component intensities were highest for the UP region and were decoupled from absorption suggesting different sources and or behavior of the absorbing and fluorescing substances. Similar non-linear relationships between $a_{\mathrm{g}} 355$ and fluorescence have been reported for the Middle Atlantic Bight (Del Vecchio and Blough, 2004). Further, the more degraded protein-like tyrosine $\mathrm{C} 3$ component was the most dominant component $(21.9 \%)$ after the $\mathrm{C} 1$ marinelike component $(32.5 \%)$ with the fresher tryptophan-like $\mathrm{C} 4$ component forming the lowest by percentage $(11.7 \%)$ in the study region (Table 3). Such signatures from marinelike and tyrosine-like fluorophores were also observed in the Sea of Okhotsk and the northwestern North Pacific Ocean (Yamashita et al., 2010) suggesting that these two components may form an important fraction of the fluorescent pool in the Pacific waters. Coastal runoff from glacial meltwater including many small rivers that empty into the Gulf of Alaska and eventually mix with the ACW as it flows along the Gulf of Alaska could also contribute to the higher concentrations of humic- and protein-like components in the UP region. Previous studies have indicated that glaciated watersheds in the Gulf of Alaska could be an important source of labile organic matter to the marine environment (Hood et al., 2009); such watersheds containing elevated levels of both tyrosine and tryptophan-like fluorophores (Fellman et al., 2010) could contribute to the ACW. Climatically driven changes in glacier melt in the Aleutian Island chain and along the Gulf of Alaska which generally have high runoff rates (Arendt et al., 2002; Hood et al., 2009) could potentially alter DOM composition of the ACW and thus the waters entering the eastern Bering Sea.

\subsection{DOM characteristics in the inner shelf region}

The inner shelf which is delineated by a front along the 40 $50 \mathrm{~m}$ isobath has a generally well-mixed water column as a result of strong tidal and wind mixing events in the summer. Waters along the inner shelf are influenced by increased coastal runoff and discharge during spring and summer from rivers such as the Kuskokwim and Yukon resulting in the highest CDOM and DOC concentrations in the study region (Table 1). Discharge from the Kuskokwim would likely be similar to the Yukon where maximum DOC concentrations and CDOM absorption were observed during the spring flush
(Spencer et al., 2008). The intensity of the five fluorescent components in particular $\mathrm{C} 1$ were also the highest but variable in the inner shelf (Table 3). Variability in both $a_{\mathrm{g}} 355$ and $S$ with sharp gradients in salinity and temperature along with mixing of the inner shelf waters with the northwestward flowing ACW results in a more complex DOM optical structure.

\subsection{DOM characteristics in the outer shelf/slope region}

Waters in the outer shelf/slope with more elevated temperatures and salinity (Fig. 3a and b) were associated with the Bering Slope Current (BSC) that flows along the outer shelf/slope bathymetry in a northwest direction (Schumacher and Stabeno, 1998). The flow is also characterized by meanders or eddies and episodic on-shelf flow that replenish nutrients onto the shelf (Stabeno and Van Meurs, 1999) resulting in a region of high and sustained productivity also known as the "green belt". Generally $a_{\mathrm{g}} 355$ and $S$ in both the surface and subsurface depths of the outermost slope stations were similar to the UP region (Figs. $3 \mathrm{e}, \mathrm{f}$ and $4 \mathrm{e}, \mathrm{f}$ ) suggesting similarities in source waters (Alaska Stream/Alaska Coastal Water). However there were exceptions to these patterns, (e.g., ls1-6 (surface) and np15 (33 m depth)) where elevated Chl fluorescence and DOC corresponded to elevated $a_{\mathrm{g}} 355$ and low slope $S$, a further indication of authochthonous CDOM (Stedmon et al., 2011). These findings are also supported by the elevated concentrations of the protein-like fluorophores, wherein, the tryptophan like $\mathrm{C} 4$ component that represents fresher DOM is elevated while the tyrosine fluorophore C3 is low (Fig. 9c and d). At station $\mathrm{mn} 20$ for example, slightly elevated $\mathrm{Chl}$ fluorescence and DOC corresponded to high $a_{\mathrm{g}} 355$ and relatively lower $S$ but equally elevated $\mathrm{C} 3$ and $\mathrm{C} 4$ suggesting the presence of both degraded and fresh DOM at this location. Further, the more elevated marine humic-like $\mathrm{C} 1$ component (and low $\mathrm{C} 2$ and $\mathrm{C} 5$ ) suggests a strong marine source of this CDOM. During 2008, the stations in the green belt region had higher algal biomass comprising of $P$. pouchetti and cryptophytes that were photo-physiologically stressed, as well as diatoms that appeared to be remnants of the spring bloom (Goes et al., 2014) supporting bacterial mediation of CDOM related to these species (Carlson et al., 1999).

\section{Conclusions}

The eastern Bering Sea encompasses a highly complex physical, biological and photochemical environment. Absorption and fluorescence spectroscopy coupled with PARAFAC analysis of CDOM revealed both autochthonous and allochthonous sources whose distribution patterns and dynamics, appeared to be strongly influenced by the presence of the cold pool. Absorption properties (absorption coefficients and spectral slope) and PARAFAC derived components of 
CDOM, in conjunction with the hydrography provided important insights into the sinks and sources of CDOM in the middle shelf. A larger cold pool during the summer of 2008 likely resulted in reduced mixing of the water column as a consequence of which CDOM in the surface mixed layer experienced enhanced photodegradation of the absorbing and humic-like fluorescence fraction of DOM. However, DOC did not significantly decrease between the surface and subsurface waters likely due to enhanced autochthonous production (e.g., protein-like amino acids) or due to the humiclike and absorbing components forming only a small fraction of the DOM pool. Previous studies have shown that the extent of the cold pool strongly influences the phytoplankton and zooplankton community in the eastern Bering Sea. More intense stratification and CDOM photodegradation of the surface mixed layer associated with a larger cold pool may have allowed light penetration to greater depths into the cold pool, where aided by nutrient availability, massive phytoplankton blooms resulted at greater depths in the northern middle shelf. With climate change potentially impacting the extent of the cold pool, changes in CDOM could impact the light field and consequently the primary production and associated trophic links in the eastern Bering Sea. CDOM optical properties were also variable across the other regions (inner shelf, Unimak Pass and outer shelf/slope regions) revealing strong linkages to climate sensitive parameters such as circulation, coastal runoff and productivity in each of the regions. Climate change impacts associated with these factors could thus potentially change the CDOM characteristics of the eastern Bering Sea.

Acknowledgements. This study was funded by NASA grants NNX07AR15G and NNX10AP10G. The authors would like to thank the National Science Foundation and the North Pacific Research Board for permission to join the BEST/BSIERP multidisciplinary cruises. Hydrological data utilized in this study was collected by NOAA, PMEL. We are grateful to William Floering of the NOAA, Pacific Marine Environmental Laboratory for help provided during the cruise and to Dr. Ray Sambrotto for the opportunity to participate in the BEST funded research cruise on the USCGC Healy.

Edited by: A. Bricaud

\section{References}

Arendt, A. A., Echelmeyer, K. A., Harrison, W. D., Lingle, C. S., and Valentine, V. B.: Rapid wastage of Alaska glaciers and their contribution to rising sea level, Science, 297, 382-386, 2002.

Benner, R. and Strom, M.: A critical evaluation of the analytical blank associated with DOC measurements by high temperature catalytic oxidation. Mar. Chem., 41, 153-160, 1993.

Benner, R., Benitez-Nelson, B., Kaiser, K., and Amon, R. M. $\mathrm{W}$.: Export of young terrigenous dissolved organic carbon from rivers to the Arctic Ocean, Geophys. Res. Lett., 31, L05305, doi:10.1029/2003GL019251, 2004.

Blough, N. V. and Del Vecchio, R.: Chromophoric DOM in the coastal environment, in: Biogeochemistry of Marine Dissolved Organic Matter, edited by: Hansell, D. A. and Carlson, C. A., Academic Press, San Diego, 509-578, 2002.

Boss, E., Pegau, W. S., Zaneveld, J. R. V., and Barnard, A. H.: Spatial and temporal variability of absorption by dissolved material at a continental shelf, J. Geophys. Res., 106, 9499-9507, 2001.

Carlson, C. A., Bates, N. R., Ducklow, H. W., and Hansell, D. A.: Estimation of bacterial respiration and growth efficiencies in the Ross Sea, Antarctica, Aquat. Microb. Ecol., 19, 229-244, 1999.

Coachman, L. K.: Circulation, water masses, and fluxes on the southeastern Bering Sea shelf, Cont. Shelf Res., 5, 23-108, 1986.

Coble, P. G.: Characterization of marine and terrestrial DOM in seawater using excitation-emission matrix spectroscopy, Mar. Chem., 51, 325-346, 1996.

Coble, P. G.: Marine optical biogeochemistry: the chemistry of ocean color, Chem. Rev., 107, 402-418, 2007.

Cooper, L. W., Benner, R., McClelland, J. W., Peterson, B. J., Holmes, R. M., Raymond, P. A., Hansell, D. A., Grebmeier, J. M., and Codispoti, L. A.: Linkages among runoff, dissolved organic carbon, and the stable oxygen isotope composition of seawater and the other water mass indicators in the Arctic Ocean, J. Geophys. Res., 110, G02013, doi:10.1029/2005JG000031, 2005.

D'Sa, E. J.: Colored dissolved organic matter in coastal waters influenced by the Atchafalaya River, USA: effects of an algal bloom, J. Appl. Remote Sens., 2, 023502, doi:10.1117/1.2838253, 2008.

D'Sa, E. J. and DiMarco, S.: Seasonal variability and controls on chromophoric dissolved organic matter in a large riverdominated coastal margin, Limnol. Oceanogr., 54, 2233-2242, 2009.

D’Sa, E. J., Steward, R. G., Vodacek, A., Blough, N. V., and Phinney, D.: Determining optical absorption of colored dissolved organic matter in seawater with a liquid capillary waveguide, Limnol. Oceanogr., 44, 1142-1148, 1999.

D’Sa, E. J., Miller, R. L., and Del Castillo, C.: Bio-optical properties and ocean color algorithms for coastal waters influenced by the Mississippi River during a cold front, Appl. Opt., 45, 7410-7428, 2006.

Del Vecchio, R. and Blough, N.: Spatial and seasonal distribution of chromophoric dissolved organic matter and dissolved organic carbon in the Middle Atlantic Bight, Mar. Chem., 89, 169-187, 2004.

Dittmar, T.: Evidence for terrigenous dissolved organic nitrogen in the Arctic deep sea, Limnol. Oceanogr., 49, 148-156, 2004.

Fellman, J. B., Spencer, R. G. M., Hernes, P. J., Edwards, R. T., D'Amore, D. V., and Hood, E.: The impact of glacier runoff on the biodegradability and biochemical composition of terrigenous dissolved organic matter in near-shore marine ecosystems, Mar. Chem., 121, 112-122, 2010.

Fichot, C. G. and Benner, R.: The spectral slope coefficient of chromophoric dissolved organic matter $\left(S_{275-295}\right)$ as a tracer of terrigenous dissolved organic carbon in river-influenced ocean margins, Limnol. Oceanogr., 57, 1453-1466, 2012.

Goes, J. I., Gomes, H. R., Haugen, E., McKee, K., D’Sa, E., Chekalyuk, A. M., Stoecker, D., Stabeno, P., Saitoh, S., and Sambrotto, R.: Fluorescence, pigment and microscopic characterization of Bering Sea phytoplankton community structure and photosyn- 
thetic competency in the presence of a Cold Pool during summer, Deep-Sea Res. Pt. II, in press, doi:10.1016/j.dsr2.2013.12.004, 2014.

Granskog, M. A.: Changes in spectral slopes of colored dissolved organic matter absorption with mixing and removal in a terrestrially dominated marine system (Hudson Bay, Canada), Mar. Chem., 134-135, 10-17, 2012.

Granskog, M. A., Stedmon C. A., Dodd P. A., Amon R. M. W., Pavlov, A. K., de Steur, L., and Hansen, E.: Characteristics of colored dissolved organic matter (CDOM) in the Arctic outflow in the Fram Strait: Assessing the changes and fate of terrigenous CDOM in the Arctic Ocean, J. Geophys. Res., 117, C12021, doi:10.1029/2012JC008075, 2012.

Grebmeier, J. M., Overland, J. E., Moore, S. E., Farley, E. V., Carmack, E. C., Cooper, L. W., Frey, K. E., Helle, J. H., McLaughlin, F. A., and McNutt, S. L.: A major ecosystem shift in the northern Bering Sea, Science, 311, 1461-1464, doi:10.1126/science.1121365, 2006.

Gregg, W. W. and Casey, N. W.: Global and regional evaluation of the SeaWiFS chlorophyll data set, Remote Sens. Environ., 93, 463-479, 2004.

Gueguen, C., Guo, L., and Tanaka, N.: Distributions and characteristics of colored dissolved organic matter in the Western Arctic Ocean, Cont. Shelf Res., 25, 1195-1207, 2005.

Gueguen, C., McLaughlin, F. A., Carmack, E. C., Itoh, M., Narita, H., and Nishino, S.: The nature of colored dissolved organic matter in the southern Canada Basin and East Siberian Sea, DeepSea Res. Pt. II, 81-84, 102-113, doi:10.1016/j.dsr2.2011.05.004, 2012.

Hansell, D. A. and Carlson, C. A.: Biogeochemistry of Marine Dissolved Organic Matter, Academic Press, San Diego, 2002.

Helms, J. R., Stubbins, A., Ritchie, J. D., Minor, E. C., Kieber, D. J., and Mopper, K.: Absorption spectral slopes and slope ratios as indicators of molecular weight, source, and photobleaching of chromophoric dissolved organic matter, Limnol. Oceanogr., 53, 955-969, 2008.

Hood, E., Fellman, J., Spencer, R. G. M., Hernes, P. J., Edwards, R., D'Amore, D., and Scott, D.: Glaciers as a source of ancient and labile organic matter to the marine environment, Nature, 462 , 1044-1048, 2009.

Jorgensen, L., Stedmon, C. A., Kragh, T., Markager, S., Middelboe, M., and Sondergaard, M.: Global trends in the fluorescence characteristics and distribution of marine dissolved organic matter, Mar. Chem., 126, 139-148, 2011.

Kachel, N. B., Hunt Jr., G. L., Salo, S. A., Schumacher, J. D., Stabeno, P. J., and Whitledge, T. E.: Characteristics and variability of the inner front of the southeastern Bering Sea, Deep-Sea Res. Pt. II, 49, 5889-5909, 2002.

Kowalczuk, P., Durako, M. J., Young, H., Kahn, A. E., Cooper, W. J., and Gonsior, M.: Characterization of dissolved organic matter fluorescence in the South Atlantic Bight with use of PARAFAC model: Interannual variability, Mar. Chem., 113, 182-196, 2009.

Luchin, V. A., Menovshchikov, V. A., Lavrentiev, V. M., and Reed, R. K.: Thermohaline structure in the Bering Sea, in: Dynamics of the Bering Sea: A summary pf physical, chemical, and biological characteristics, and a synopsis of research on the Bering Sea, edited by: Loughlin T. R. and Ohtani, K., AK-SG-99-03, North Pacific Marine Science Organization (PICES) University of Alaska Sea Grant, Fairbanks, AK, 61-91, 1999.
Mathis, J. T., Cross, J. N., Bates, N. R., Bradley Moran, S., Lomas, M. W., Mordy, C. W., and Stabeno, P. J.: Seasonal distribution of dissolved inorganic carbon and net community production on the Bering Sea shelf, Biogeosciences, 7, 1769-1787, doi:10.5194/bg-7-1769-2010, 2010.

Matsuoka, A., Huot, Y. Shimada, K., Saitoh, S., and Babin, M.: Biooptical characteristics of the western Arctic Ocean: implications for ocean color, Can. J. Remote Sens., 33, 503-518, 2007.

Matsuoka, A., Bricaud, A., Benner, R., Para, J., Sempéré, R., Prieur, L., Bélanger, S., and Babin, M.: Tracing the transport of colored dissolved organic matter in water masses of the Southern Beaufort Sea: relationship with hydrographic characteristics, Biogeosciences, 9, 925-940, doi:10.5194/bg-9-925-2012, 2012.

Mayer, L. M., Schick, L. L., and Loder III, T. C.: Dissolved protein fluorescence in two Maine estuaries, Mar. Chem., 64, 171-179, 1999.

Mopper, K. and Kieber, D. J.: Photochemistry and the cycling of carbon, sulfur, nitrogen, and phosphorus, in: Biogeochemistry of Marine Dissolved Organic Matter, edited by: Carlson, C. and Hansell, D., Academic Press, 455-508, 2002.

Mopper, K. and Schultz, C. A.: Fluorescence as a possible tool for studying the nature and water column distribution of DOC components, Mar. Chem., 41, 229-238, 1993.

Moran, M. A., Sheldon, W. M., and Zepp, R. G.: Carbon loss and optical property changes during long-term photochemical and biological degradation of estuarine dissolved organic matter, Limnol. Oceanogr., 45, 1254-1264, 2000.

Murphy, K. R., Stedmon, C. A., Waite, T. D., and Ruiz, G. M.: Distinguishing between terrestrial and autochthonous organic matter sources in marine environments using fluorescence spectroscopy, Mar. Chem., 108, 40-58, 2008.

Naik, P., D’Sa, E. J., Gomes, H. R., Goes, J. I., and Mouw, C. B.: Light absorption properties of southeastern Bering Sea waters: Analysis, parameterization and implications for remote sensing, Remote Sens. Environ., 134, 120-134, 2013.

Nelson, N. B. and Siegel, D. A.: The global distribution and dynamics of chromophoric dissolved organic matter, Annu. Rev. Mar. Sci., 5, 447-476, 2013.

Nelson, N. B., Siegel, D. A., Carlson, C. A., and Swan, C. M.: Tracing global biogeochemical cycles and meridional overturning circulation using chromophoric dissolved organic matter, Geophys. Res. Lett., 37, L03610, doi:1029/2009GL042325, 2010.

Overland, J. E. and Stabeno, P. J.: Is the climate of the Bering Sea warming and affecting the ecosystem?, Eos Trans. AGU, 85, 309-316, 2004.

Romera-Castillo, C., Sarmento, H., Alvarez-Salgado, X. A., Gasol, J. M., and Marrase, C.: Production of chromophoric dissolved organic matter by marine phytoplankton, Limnol. Oceanogr., 55, 446-454, 2010.

Sasaki, H., Saitoh, S., and Kishino, M.: Bio-optical properties of seawater in the western subarctic gyre and Alaskan gyre in the subarctic north Pacific and southern Bering Sea during the summer of 1997, J. Oceanogr., 57, 275-284, 2001.

Schlitzer, R.: Ocean Data View, available at: http://www. awi-bremerhaven.de/GEO/ODV/, 2004.

Schumacher, J. D. and Stabeno, P. J.: The continental shelf of the Bering Sea, in: The Sea: Vol. 11, The Global Coastal Ocean: Regional Studies and Synthesis, New York, NY, John Wiley and Sons Inc., 789-822, 1998. 
Shaver, G. R., Billings, W. D., Chapin III, F. S., Giblin, A. E., Nadelhoffer, K. J., Oechel, W. C., and Rastetter, E. B.: Global change and the carbon balance of arctic ecosystems, Bioscience, 42, 433-441, 1992.

Shen, Y., Fichot, C. G., and Benner, R.: Dissolved organic matter composition and bioavailability reflect ecosystem productivity in the Western Arctic Ocean, Biogeosciences, 9, 4993-5005, doi:10.5194/bg-9-4993-2012, 2012.

Siegel, D. A., Maritorena, S., Nelson, N. B., Hansell, D. A., and Lorenzi-Kayser, M.: Global distribution and dynamics of colored dissolved and detrital organic materials, J. Geophys. Res., 107, 3228, doi:10.1029/2001JC000965, 2002.

Sigler, M. F., Harvey, H. R., Ashjian, C. J., Lomas, M. W., Napp, J. M., Stabeno, P. J., and Pelt, T. I. V.: How Does Climate Change Affect the Bering Sea Ecosystem?, EOS Trans. AGU, 91, 457458, doi:10.1029/2010EO480001, 2010.

Singh, S., D'Sa, E. J., and Swenson, E. M.: Chromophoric dissolved organic matter (CDOM) variability in Barataria Basin using excitation-emission matrix (EEM) fluorescence and parallel factor analysis (PARAFAC), Sci. Total Environ., 408, 32113222, 2010.

Sharp, J. H.: Analytical methods for dissolved organic carbon, nitrogen, and phosphorus, in: Biogeochemistry of Marine Dissolved Organic Matter, edited by: Hansell, D. A. and Carlson, C. A., Academic Press, San Diego, 35-90, 2002.

Spencer, R. G. M., Aiken, G. R., Wickland, K. P., Striegl, R. G., and Hernes, P. J.: Seasonal and spatial variability in dissolved organic matter quantity and composition from the Yukon River basin, Alaska, Global Biogeochem. Cy., 22, BG4002, doi:10.1029/2008GB003231, 2008.

Stabeno, P. J. and Van Meurs, P.: Evidence of episodic on-shelf flow in the southeastern Bering Sea, J. Geophys. Res., 104, 2971529720, 1999.

Stabeno, P. J., Schumacher, J. D., and Ohtani, K.: The physical oceanography of the Bering Sea, in: Dynamics of the Bering Sea, North Pacific Marine Science Organization (PICES), edited by: Loughlin, T. R. and Ohtani, K., University of Alaska Sea Grants Fairbanks, Alaska, 1-28, 1999.

Stabeno, P. J., Farley Jr., E. V., Kachel, N. B., Moore, S., Mordy, C. W., Napp, J. M., Overland, J. E., Pinchuk, A. I., and Sigler, M. F.: A comparison of the physics of the northern and southern shelves of the eastern Bering Sea and some implications for the ecosystem, Deep-Sea Res. Pt. II, 65-70, 14-30, 2012a.

Stabeno, P. J., Kachel, N. B., Moore, S. E., Napp, J. M., Sigler, M., Yamaguchi, A., and Zerbini, A. N.: Comparison of warm and cold years on the southeastern Bering Sea shelf and some implications for the ecosystem, Deep-Sea Res. Pt. II, 65-70, 3145, $2012 b$.

Stedmon, C. A. and Bro, R.: Characterizing dissolved organic matter fluorescence with parallel factor analysis: a tutorial, Limnol. Oceanogr.-Methods, 6, 572-579, 2008.
Stedmon, C. A. and Markager, S.: The optics of chromophoric dissolved organic matter (CDOM) in the Greenland Sea: An algorithm for differentiation between marine and terrestrially derived organic matter, Limnol. Oceanogr., 46, 2087-2093, 2001.

Stedmon, C. A. and Markager, S.: Tracing the production and degradation of autochthonous fractions of dissolved organic matter using fluorescence analysis, Limnol. Oceanogr., 50, 1415-1426, 2005a.

Stedmon, C. A. and Markager, S.: Resolving the variability in dissolved organic matter fluorescence in a temperate estuary and its catchment using PARAFAC analysis, Limnol. Oceanogr., 50, 686-697, 2005b.

Stedmon, C. A., Markager, S., and Bro, R.: Tracing dissolved organic matter in aquatic environments using a new approach to fluorescence spectroscopy, Mar. Chem., 82, 239-254, 2003.

Stedmon, C. A., Amon, R. M. W., Rinehart, A. J., and Walker, S. A.: The supply and characteristics of colored dissolved organic matter (CDOM) in the Arctic Ocean: Pan Arctic trends and differences, Mar. Chem., 124, 108-118, 2011.

Walker, S. A., Amon, R. M. W., Stedmon, S., Duan, S., and Louchouarn, P.: The use of PARAFAC modeling to trace terrestrial dissolved organic matter and fingerprint water masses in coastal Canadian Arctic surface waters, J. Geophys. Res., 114, G00F06, doi:10.1029/2009JG000990, 2009.

Walsh, J. J. and McRoy, C. P.: Ecosystem analysis in the southeastern Bering Sea, Cont. Shelf Res., 5, 259-288, 1986.

Wang, J., Hu, H., Goes, J., Miksis-Olds, J., Mouw, C., D’Sa, E., Gomes, H., Wang, D. R., Mizobata, K., Saitoh, S., and Luo, L.: A modeling study of seasonal variations of sea ice and plankton in the Bering and Chukchi Seas during 2007-2008, J. Geophys. Res., 118, 1-14, 2013.

Yamashita, Y., Jaffe, R., Maie, N., and Tanoue, E.: Assessing the dynamics of dissolved organic matter (DOM) in coastal environments by excitation emission matrix fluorescence and parallel factor analysis (EEM-PARAFAC), Limnol. Oceanogr., 53, 19001908, 2008.

Yamashita, Y., Cory, R. M., Nishioka, J., Kuma, K., Tanoue, E., and Jaffe, R.: Fluorescence characteristics of dissolved organic matter in the deep waters of the Okhotsk Sea and the northwestern North Pacific Ocean, Deep-Sea Res. Pt. II, 57, 1478-1485, 2010.

Yamashita, Y., Nosaka, Y., Suzuki, K., Ogawa, H., Takahashi, K., and Saito, H.: Photobleaching as a factor controlling spectral characteristics of chromophoric dissolved organic matter in open ocean, Biogeosciences, 10, 7207-7217, doi:10.5194/bg-107207-2013, 2013.

Zhang, J., Woodgate, R., and Mangiameli, S.: Towards seasonal prediction of the distribution and extent of cold bottom waters on the Bering Sea shelf, Deep-Sea Res. Pt. II, 65, 58-71, 2012. 